\title{
NOVÉ POZNATKY K OHRAZENÝM STŘEDOVĚKÝM VESNICÍM NA JIŽNÍ MORAVĚ Z POHLEDU DÁLKOVÉHO PRŮZKUMU ZEMĚ
}

\author{
MICHAL VÁGNER - JAN ŠKVRŇÁK - PETR DRESLER
}

\begin{abstract}
Abstrakt: V rámci letecké prospekce uskutečněné na územi jižni Moravy počátkem 90. let 20. století se podařilo v mistech několika zaniklých středověkých vesnic identifikovat lineární porostové př́znaky, které byly interpretovány jako vnějši ohrazení v podobě přikopů, širokých i několik metrů. Studiem historických mapových archiválii a nejnovějšich družicových a leteckých ortofotosnímků se podařilo nově identifikovat stejný typ ohrazení u dalšich zaniklých středověkých vesnic a významně tak rozšírit počet těchto lokalit ve sledovaném regionu.
\end{abstract}

Kličová slova: středověk-zaniklé vesnice-ohrazené areály-jižní Morava-dálkový průzkum Země.

New information about enclosed medieval villages in South Moravia from the perspective of remote sensing

Abstract: Within the aerial prospection carried out in the territory of South Moravia in the early 1990s, linear crop marks had been identified in the place of several deserted medieval villages, and were interpreted as an outer enclosure in the form of a several metres wide moat. In the course of the study of historical maps and the latest satellite and vertical aerial photography images, the same type of enclosures was identified with other deserted medieval villages, which significantly increased the number of these sites in the observed region.

Key words: Middle Ages - deserted villages - enclosed areas - South Moravia - remote sensing.

\section{Úvod}

Z užší oblasti jižní Moravy - Mikulovska, Drnholecka a části Břeclavska - máme o existenci vrcholně středověkých ohrazených vesnic a městeček doklady z lichtenštejnského urbáře z roku 1414 (Bretholz 1930). V tomto písemném prameni jsou u třinácti dodnes existujících vsí a čtyř zaniklých vesnic zmíněni držitelé čtvrtlánů, kteří měli v rámci jedné ze svých poddanských povinností určeno zavírat a otevírat bránu, popřípadě brány. Tento doklad vede k logickému závěru, že tyto lokality musely být v minulosti obehnány nějakou formou vnějšího ohrazení. Bohužel, v rámci moravské stř̌edověké archeologie byla tato problematika po dlouhou dobu na okraji badatelského zájmu. Výjimku tvořil Z. Měřínský, který se k ní letmo vyjádřil na počátku 80. let 20. století (1982). Z terénních prospekcí se vědělo o zaniklých Potvorovicích na Hodonínsku (k. ú. Nový Poddvorov; Klanica 1973; Měřínský 1977) a zaniklých Dašovicích (k. ú. Štěmechy; Měřínský 1976), které se nachází na moravské straně Českomoravské vrchoviny. V Čechách se ohrazením u vesnických sídel částečně zabýval Z. Smetánka, a to v souvislosti s rozborem ikonografické stránky Mandevillova cestopisu (Smetánka 1985) a ve spojitosti se zděným ohrazením archeologicky zkoumané ZSV Svídné (Smetánka 1988). Ohrazeným vesnickým sídlům byla věnována pozornost i v sousedních zemích. V krátkosti se $\mathrm{k}$ nim vyjádřil ve své souhrnné práci o středověkých vesnicích na Slovensku A. Habovštiak, který zmiňuje ohrazení u zaniklé vsi Pavlany, jež byla podle všeho ohrazena 6 m širokým a 1,3 m hlubokým př́kopem (Habovštiak 1985, 213). Nedaleko dolnorakouského Orth an der Donau byla v 60. letech 20. století zkoumána zaniklá ohrazená vesnice Gang (Felgenhauer-Felgenhauer-Schmidt 1969), která měla pravidelný obdélný půdorys a po svém obvodu byla obehnána jak příkopem, tak i hliněným náspem. V nedávné době se podařilo díky leteckému laserovému skenování zmapovat v lesích okolo dolnorakouské obce Enzersdorf im Thale několik dalších zaniklých středověkých vesnic, které byly v minulosti ohrazeny př́ikopem a hliněným náspem. Mimo lokalitu Loidenbrunn, která má podle nově zjištěných informací složitější půdorysnou dispozici, měly zbylé zachycené zaniklé vsi obdélný půdorys, přičemž jejich delší osou procházela komunikace. Jedná se například o zaniklý Krales, v jehož intravilánu se nachází i menší feudální sídlo čtvercové dispozice, či o nedaleký 
Unter-Abtsdorf (více na internetové platformě obce Enzersdorf im Thale - Kleinkadolz v sekci „Versunkene Orte“). V rámci letecké prospekce z území Dolního Rakouska bylo ohrazení ve formě př́ikopů odhaleno u zaniklé vesnice Rotensee (Scharrer-Liska 2007, 71-72), která se nachází u česko-rakouských hranic severozápadně od Laa an der Thaya, a u zaniklé vsi Roking (Kühtreiber 2015, 236, 237), která se nachází na katastru obce Reisenberg v okrese Baden.

Z Německa známe hned několik zaniklých ohrazených vesnic. Dobrým př́íkladem může být zaniklá středověká ves Miltendorf, která se nachází nedaleko obce Reetz v Braniborsku. Při záchranném archeologickém výzkumu realizovaném v roce 1991/1992 se podařilo odkrýt její severozápadní část. Mimo rozličných sídlištních objektů byl zachycen i pravoúhlý př́ikop, který vesnici ohrazoval z její severozápadní strany (Biermann 2003; 2010; Biermann-Mangelsdorf 2005; Warnke 1993).

Na území Moravy bylo ohrazení u vesnice doloženo archeologickým výzkumem v 80. letech 20. století. Při záchranném výzkumu v intravilánu obce Strachotín, u které jsou v lichtenštejnském urbáŕi uvedeni tři čtvrtláníci s povinností na noc zavírat bránu, se podařilo vedle běžných sídlištních objektů zachytit i část 3,5-4 m širokého př́ikopu (Klanicová-Měrínský 1983, 47; Měřínský 1985, 219) o hloubce ca 2 m (obr. 1).
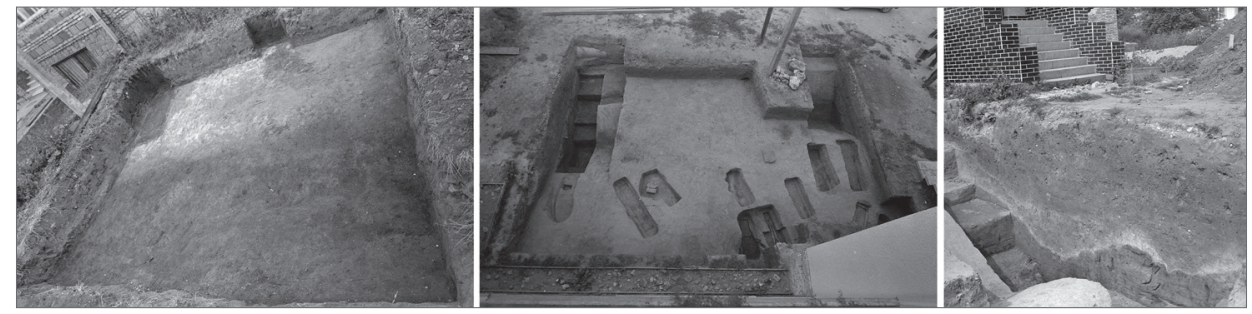

Obr. 1. Záchranný archeologický výzkum v intravilánu obce Strachotín v letech 1980-1981, při kterém se mimo jiné podařilo zachytit i část vnějš́ího středověkého příkopu. Vlevo část zkoumané plochy s rýsujícím se příkopem v popředí (č. n. 21913/8); uprostřed pohled na plochu v prủběhu výzkumu; v pozadí jsou vidět dva řezy zachyceným př́íkopem (č. n. 21913/3); vpravo detail řezu př́íkopem (č. n. 22022/1). Zdroj Archiv ARÚ Brno.

Abb. 1. In den Jahren 1980-1981 durchgeführte archäologische Rettungsgrabung im Intravillan der Gemeinde Strachotín, bei der es unter anderem gelang, auch einen Teil eines mittelalterlichen Außengrabens zu erfassen. Links Teil der untersuchten Fläche mit sich im Vordergrund abzeichnendem Graben (Nummer des Negativs 21913/8); in der Mitte Blick auf die Fläche während der Grabung; im Hintergrund sind zwei Schnitte durch den erfassten Graben zu sehen (Nummer des Negativs 21913/3); rechts Detail des Schnittes durch den Graben (Nummer des Negativs 22022/1). Quelle Archiv des Archäologischen Instituts Brno.

Nové informace $\mathrm{v}$ otázce ohrazených středověkých vesnic přinesla až letecká prospekce M. Bálka na počátku 90. let 20. století. V místech několika zaniklých vesnic byly identifikovány lineární porostové př́źznaky, které byly posléze interpretovány jako zbytky vnějšího ohrazení ve formě prŕikopů. Ty byly nově objeveny u tř́i zaniklých vesnic - Koválova, Topolan a Želic (obr. 3,7$)$. Zároveň se podařilo potvrdit ohrazení v podobě př́íkopů u zaniklých Hroznětic (obr. 3), u nichž jsou v lichtenštejnském urbáři zmíněny dvě brány obsluhované čtyřmi čtvrtláníky. Výsledky leteckých prospekcí a povrchových sběrů na vybraných lokalitách pak byly shrnuty J. Ungerem a M. Bálkem v roce 1996 (Bálek 1997, 307, 311; Bálek-Unger 1996; 1996a).

V posledních letech lze k dálkovému archeologickému průzkumu využít nejrůznější archivy digitálních ortofotosnímků, které jsou volně k nahlédnutí na různých mapových portálech, anebo dostupné v GIS ve formě dálkových WMS (Web Map Service) služeb. Tyto ortofotomapy jsou z větši části pořízeny ve vhodných vegetačních podmínkách a mohou tak být alternativou ke klasické šikmé letecké prospekci, která je z hlediska vybavení, času a finančních nákladů poměrně náročnou metodou. Díky těmto digitálním ortofotosnímkům lze bez problémů identifikovat a prostorově vymezit kromě starších i vrcholně středověké archeologické lokality (Dresler-Tencer 
2016; Dresler-Tencer-Vágner 2015a). V předkládaném př́ispěvku byly k identifikaci porostových př́znaků u jednotlivých zaniklých vesnic využity ortofotosnímky od společnosti TopGis s. r. o. (dříve Geodis Brno), která již od 90. let minulého století opakovaně provádí kompletní blokové snímkování ČR (Gojda 2017, 336).

Velkou měrou jsou nápomocny i historické mapy z 19. století, zejména pak II. a III. vojenské mapování, indikační skici a císařské povinné otisky map stabilního katastru Moravy a Slezska z let 1824-1843. Tyto mapové archiválie poskytují důležité doplňující informace jednak o půdorysném tvaru ohrazených areálů, jednak také o polohovém umístění sledovaných sídel vůči jiným, dnes již neexistujícím krajinným prvkům, např́íklad zaniklým vodotečím či historickým komunikacím.

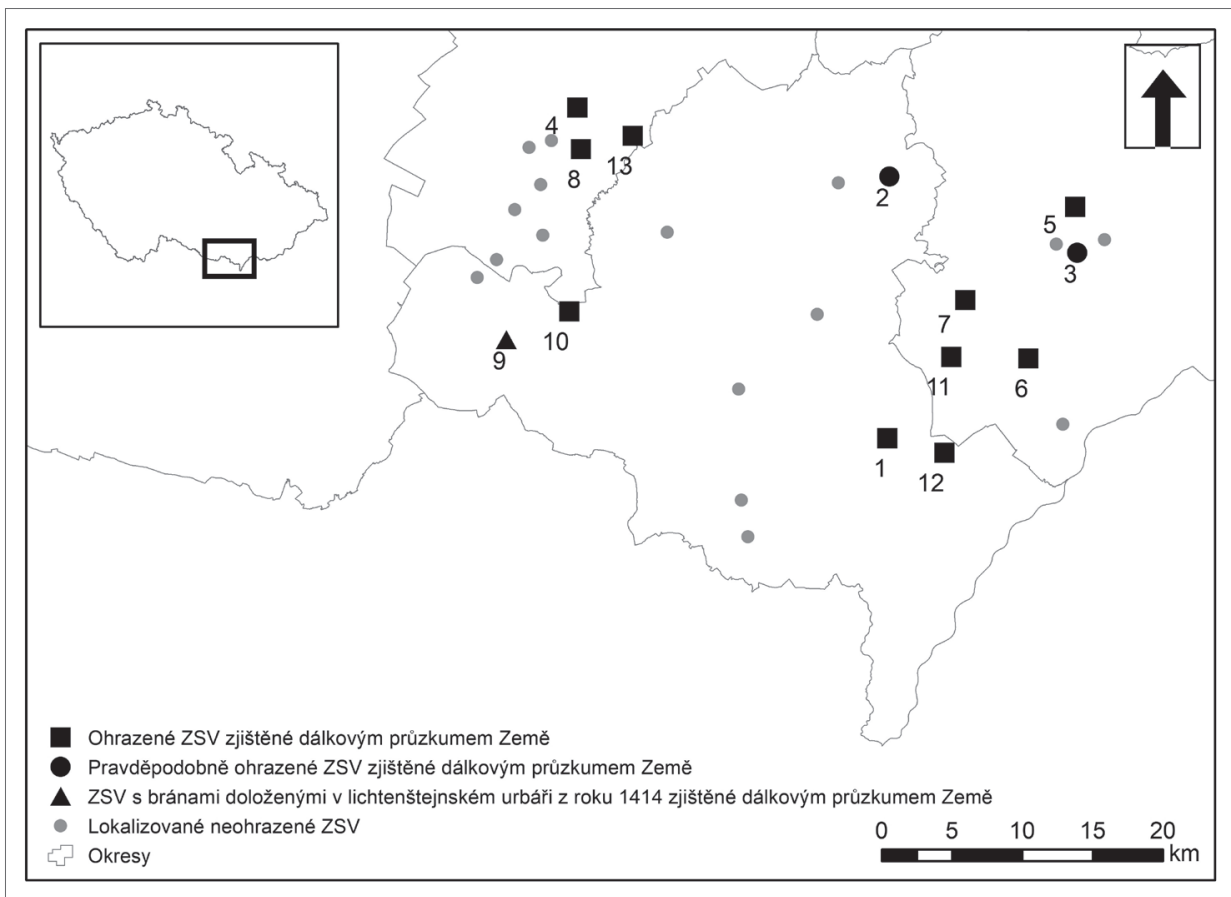

Obr. 2. Polohopisně definované ohrazené a neohrazené zaniklé středověké vesnice na sledovaném území zjištěné za pomoci dálkového prủzkumu Země. 1 - Prechov; 2 - Divice; 3 - Jarohněvice; 4 - Koválov; 5 - Mistř́n; 6 - Kapansko; 7 - Hroznětice; 8 -Vsisko; 9 - Topolany; 10 - Potvorovice; 11 - Bohumělice; 12 - Opatovice; 13 - Želice.

Abb. 2. Lagemäßig definierte, durch Fernuntersuchung ermittelte umfriedete und nicht umfriedete mittelalterliche Dorfwüstungen im beobachteten Gebiet. 1 - Prechov; 2 - Divice; 3 - Jarohněvice; 4 - Koválov; 5 - Mistř́n; 6 - Kapansko; 7 - Hroznětice; 8 - Vsisko; 9 - Topolany; 10 - Potvorovice; 11 - Bohumělice; 12 - Opatovice; 13 - Želice.

Prechov (k. ú. Moravský Žižkov, okr. Břeclav; obr. 4:1)

První zmínka o ZSV Prechov pochází z roku 1347, kdy měl vlastnit polovinu vsi o 25 lánech pustiměřský klášter, avšak s tím, že ji držel starobřeclavský farář (CDM VII, 524 č. 708). Někdy v druhé polovině 14. století ves zpustla (Hosák 1967, 22, 73). Již jako pustou ji roce 1391 dává pustiměřský klášter po dobu života Přechovi z Trmačova, který ji měl znovu obnovit a osadit lidmi. Kromě 25 lánů zde měli být vysazeni i dva podsedci. Přech dostal dědičně dvůr se třemi lány, z něhož však měl sloužit klášteru (CDM XII, 32-33 č. 42-43). Břeclavské panství, 
včetně pustých vsí Prechov a Ulva, vlastnili nejpozději od začátku 15. století Lichtenštejnové (Bretholz 1930, 145).

Jako pustá se ves opět jmenuje v letech 1414 (Bretholz 1930, 145) a 1492 (LCS VII, 56 č. 335) a poté v letech 1513 (PB X, 70), 1514 (PB X, 78), 1555 (Zemek 1979, 212 č. 36), 1557 (PB XXII, 53) a 1601 (ZDB III, 345 č. 52). Podle toho, že je v lichtenštejnském urbáři uvedena již jako pustá, lze soudit, že podruhé a definitivně zanikla někdy na přelomu 14. a 15. století, a nikoliv v druhé polovině 15. století, jak je uváděno v literatuře (Hosák-Šrámek 1980, 304). Pozemky, které patřily k zaniklé vsi, obdělávali poddaní z Velkých Bílovic a Podivína (Nekuda 1961, 34).

Podle písemných pramenů stávala vesnice v místech dvora Prechov, který se nachází jižně od Moravského Žižkova. V rámci letecké prospekce, která byla provedena v roce 2006 Ústavem archeologické památkové péče v Brně, byly na poli jižně od tohoto dvora a východně od Žižkovského potoka v trati Smolínkova špice zjištěny ve vzdálenosti ca $4 \mathrm{~m}$ od sebe dvě paralelní linie v orientaci západ-východ. Šírka objektů byla ca $2 \mathrm{~m}$ a patrné byly v délce $40 \mathrm{~m}$. Obě linie se posléze stáčely k severu, kde se vytrácely (Čižmář-Čižmář-Marečková 2007, 545). Na novějším ortofotosnímku z roku 2009 jsou tyto porostové příznaky patrné na obou stranách Žižkovského potoka, a to v daleko větší míře. Jedná se pravděpodobně o pozůstatky př́íkopů, které v minulosti ohrazovaly areál ZSV Prechov. Na západní straně potoka je ve vzdálenosti ca $140 \mathrm{~m}$ dobře viditelný dvojitý př́íkop, který se táhne v délce ca $550 \mathrm{~m}$ zhruba ve směru sever-jih. Stejná situace se opakuje i na východní straně vodoteče, a to ve vzdálenosti $130 \mathrm{~m}$ od potoka. Na severovýchodní a jihovýchodní straně se prŕíkop stáčí směrem na severozápad a tvoří tak zbytky nároží. V severozápadní a jihozápadní části vesnice pak nejsou stopy po nároží patrné. V jihovýchodní části ohrazeného areálu se dvojitý příkop vytrácí do jediné linie, ale to je pravděpodobně zapř́ičiněno špatnou viditelností porostových př́iznaků. Ve vzdálenosti zhruba $150 \mathrm{~m}$ severně od jižní strany vesnice lze na ortofotosnímcích pozorovat další lineární porostové př́znaky, které se táhnou v délce ca 220 m ve směru východ-západ. Podle digitálního modelu reliéfu České republiky 5. generace (ČÚZK DMR 5G) se jedná o pozůstatek hliněného náspu. Podle II. vojenského mapování z roku 1827 se v těchto místech nacházela hráz rybníka.

Zaniklá středověká vesnice Prechov se tedy pravděpodobně nacházela $250 \mathrm{~m}$ jihozápadním směrem od dvora Prechov a asi 2,5 km jihozápadně od středu obce Moravský Žižkov. Lokalita se rozkládá v rovinatém terénu v nadmořské výšce ca $168 \mathrm{~m} \mathrm{n}$. m., a to na dlouhodobě obdělávaném poli. Jejím středem prochází Žižkovský potok. Jak se s pomocí ortofotosnímků ukázalo, vesnice byla ohrazena dvojitým př́íkopem, a to minimálně z jižní, západní a východní strany. Př́ikop ohrazoval obdélný areál o velikosti $630 \times 300 \mathrm{~m}$ a rozloze 17,5 ha. K její vnitřní struktuře a k otázce dalšího průběhu zbytku ohrazení by mohla v budoucnu dopomoci geofyzikální prospekce. Ta už zde byla v omezené míre provedena v roce 2013, a to v jihovýchodní části lokality. V těchto místech se prospekcí podařilo zachytit zbytek nároží, které sestávalo ze dvou paralelních lineárních anomálií. Ty byly interpretovány jako dvojice př́íkopů.

Divice (k. ú. Brumovice, okr. Břeclav; obr. 4:2)

Zaniklá ves Divice se nachází v trati Úlehle v nadmořské výšce $215 \mathrm{~m} \mathrm{n}$. m., ve vzdálenosti 1,7 km severně od středu obce Brumovice. Rozkládá se na severním svahu mírného údolí, které se svažuje směrem k Divickému potoku. První zmínka o vsi pochází již z roku 1234, kdy se podle této lokality píše Předbor a jeho syn Přibyslav (CDB III/1, 113 č. 97). V roce 1283 a 1286 se podle Divic píše jistý Jakub (CDB VI, 323 č. 269). V roce 1348 Racek s bratry prodává Mikeši ze Senice 5,5 lánu, třetinu ze dvou popluží a patronátní právo zdejšího kostela (ZDB, 2 č. 6). Mikeš ze Senice se záhy začne psát podle této lokality a majetek převádí svým bratrům (ZDB, 28 č. 158). Další část vsi převádí v roce 1358 Záviš z Třešti Boršovi z Loučky (ZDB, 30 č. 211), téhož roku kupuje Kuneš z Křepic od Jindřicha z Divic dvůr a od Dluhomila tři lány (ZDB, 38-39 č. 450-451). V roce 1371 Mikeš a Proček prodávají Kuníkovi z Drahotuš (viniční) horu Hráz (ZDB, 93 č. 473, 477). Kuník vinice a dvůr o pět let později prodává bratrům z Lilče (ZDB, 
119 č. 363). V roce 1390 zde prodává farář z Habrovan Mikuláš Ješkovi z Hvězdlic dvůr, čtyři lány a čtyři podsedky (ZDB, 189 č. 711). Poslední zpráva o vsi je z roku 1459, v roce 1561 je uváděn už jen divický rybník (Nekuda 1961, 91).

Dle písemných pramenů na lokalitě stával kostel a pravděpodobně i menší opevněné sídlo. Obě stavby byly doloženy archeologickým výzkumem v 80. letech 20. století. Opevněné sídlo typu motte se nacházelo na nepatrném kopečku o průměru 30 m uvnitř areálu zaniklé vesnice a bylo obklopeno $6 \mathrm{~m}$ širokým a 2,5 m hlubokým prŕíkopem. Zajímavým zjištěním bylo, že samotné sídlo bylo založeno na kulturní vrstvě obsahující keramiku jak z první poloviny 13. století, tak i z poloviny druhé. Vznik opevněného sídla lze tedy spojit spíše se jménem výše zmíněného Jakuba z Divic než se jmény Předbora a Přibyslava, kteří se podle této lokality psali jako první již v roce 1234. Ti měli ve vesnici své sídlo pravděpodobně na jiném místě (Unger 1987a; 1988). Necelých 80 m jižně od opevněného sídla pak byly odkryty základy menšího, dvoufázového kamenného kostela s obdélným půdorysem, v jehož okolí bylo prozkoumáno i několik hrobů (Čermák 2009; Unger 1988; 1992; 2009).

Zbytky opevněného sídla jsou díky porostovým příznakům dobře patrné na ortofotosnímcích z let 2009 a 2015 a na leteckých snímcích pořízených M. Bálkem v roce 1998 (obr. 3). Na nich lze sledovat asi $6 \mathrm{~m}$ široký tmavý pás ve tvaru čtverce, který vymezuje plochu ca $35 \times 35 \mathrm{~m}$. Jedná se o zbytky př́kopu, který byl zachycen archeologickým výzkumem v roce 1985 . Pouze v severovýchodním rohu je průběh prríkopu přerušen, což může být $\mathrm{v}$ těchto místech způsobeno špatnou čitelností porostových příznaků. Na ortofotosnímku z roku 2009 je dále patrný tmavší pás o šiřce ca $6 \mathrm{~m}$, který se táhne od jihozápadního nároží příkopu směrem k jihovýchodu. Zde je interpretace nejasná. Mohlo by se jednat o zbytky dalšího příkopu, anebo například o pozůstatky zaniklé komunikace. Jižní stranu lokality ohraničuje ca 6 metrů široký a 240 m dlouhý tmavší pás porostových příznaků, který je viditelný na ortofotosnímcích z let 2009 a 2015 . V tomto případě by se mohlo jednat o část př́ikopu, který ohrazoval vesnici z jižní strany. Na východní straně se nacházelo výše zmíněné opevněné sídlo. Průběh ohrazení v západní části je nejasný. Severní strana vesnice mohla být vymezena dnešním Divickým potokem. Nelze ovšem vyloučit, že osídlení pokračuje na druhé straně potoka. Uvnitř předpokládaného ohrazeného areálu vesnice je na ortofotosnímcích z let 2009 a 2015 patrno nejméně pět obdélných porostových př́znaků. Jejich rozměry jsou v průměru totožné, $12 \times 20 \mathrm{~m}$, a jsou od sebe vzdáleny v pravidelných rozestupech 13 až $18 \mathrm{~m}$. V tomto případě lze uvažovat, že zde porostové př́íznaky indikují pravděpodobné zbytky jednotlivých usedlostí. Poloha zaniklého kostela, respektive plocha archeologického výzkumu, při němž byl kostel odkryt, není na ortofotosnímcích jasně patrná. Zřejmě se však může jednat o tmavší obdélný porostový př́iznak s nezřetelnými hranicemi, který je viditelný na ortofotosnímku jak z roku 2009, tak i 2015. Nachází se zhruba 90 m jižně od středu opevněného sídla. Toto umístění by souhlasilo i s popisem J. Ungera $(1988,369 ; 2009,150)$.

Jarohněvice (k. ú. Dubňany, okr. Hodonín; obr. 4:3)

Od konce 15. století započala na katastru Dubňan rozsáhlá výstavba rybníků, z nichž se do dnešních dnů zachoval pouze jeden - tzv. Jarohněvický. Stejnojmenný název nesl i hospodářský dvůr, který se nacházel v těsné blízkosti jeho hráze (dnes se zde nachází stejnojmenná městská část Dubňan), a také zaniklá vesnice Jarohněvice, která se podle lidové tradice a písemných pramenů měla nacházet někde $\mathrm{v}$ jeho okolí. V hodonínském urbáři z roku 1600 jsou zmíněny i jména ostatních rybníků z katastru. Kromě Jarohněvského starého, je zde zmíněn druhý Jarohněvský rybník, Mokroňovský, horní a dolní Nadýmáček a rybník pod Dubňany při Doubravě (Vařeka 2012, 251). Na katastru Dubňan by se měla nacházet i další zaniklá ves, která nesla stejné jméno jako jeden z rybníků, a to tzv. Mokronosy (též Mokronossie, Mokronossy, Mokrowitz). O polohopisném umístění obou zaniklých vesnic - Mokronos a Jarohněvic - se však dodnes vedou spory.

Zaniklá středověká ves Jarohněvice (Jaroňovice, Jarohnyewicz, Geranowicz) se s největší pravděpodobností nacházela na rozmezí dvou dnešních tratí Louky od valů a Kostelisko, které se 
rozkládají asi 3 km severozápadně od středu obce Dubňany a necelých 350 m východně od řeky Kyjovky (Stupavy) v nadmořské výšce ca 175 m n. m. Nejistota v lokalizaci obou zaniklých vsí byla dána tím, že ve starší literatuře je v trati Kostelisko uváděna i ZSV Mokronosy (Červinka 1942, 35; Oharek 1892, 323), a tato polohopisná informace byla dále přejímána (Nekuda 1961, 65), kdežto ZSV Jarohněvice byla lokalizována do několika poloh, například i do míst dnešního Jarohněvického rybníka (též autory článku Dresler-Vágner 2018). Pochyby o nepřesné lokalizaci, respektive o polohopisné záměně obou vesnic, vyslovil v minulosti dubňanský historik V. Ilčík $(1999,37)$, který lokalizuje ZSV Mokronosy do údolí mezi Šardicemi a ústím Šardického potoka do Kyjovky, tedy do míst, kde se nachází dnešní trat’s názvem Mokroňovsko. Tato informace je známá i ze starší literatury, protože K. Hlavinka a J. Noháč píší o Mokronosích již v roce 1926 jako o pusté vsi pod Šardicemi, která „obsahovala východní část dnešního hovoranského katastru po obou stranách šardického potoka, po lesiky Oboru a Hájek" (Hlavinka-Noháč-Kratochvíl 1926, 194). Tomu, že se ZSV Mokrosnosy nacházela právě v těchto místech, pak nepřímo napovídá právě tvar hovoranského katastrálního území, protože po zániku vesnice její pozemky obdělávali poddaní z Hovoran a z Dubňan a část pozemků patřila panskému dvoru (PH 1681), a část těchto pozemků pak byla začleněna do hovoranského katastru. Tato domněnka pak byla potvrzena i po archeologické stránce v roce 2013. Při záchranném archeologickém výzkumu realizovaném brněnským Ústavem archeologické památkové péče, v. v. i., bylo v trati Mokroňovsko odkryto 32 sídlištních objektů (povětšinou kůlové jamky a několik různorodých sídlištních jam menších rozměrů), několik menších žlabových objektů a zejména pak přibližně čtvercová studna s dochovaným dřevěným bedněním. Po celé ploše byla zaznamenána mocná kulturní vrstva s keramikou datovanou předběžně do druhé poloviny 13. století. Do tohoto období byly datovány i všechny ostatní nálezy (Lečbych 2017, 216). Tomu sice neodpovídá první zmínka o vesnici, která pochází z roku 1349, kdy ji vlastnil Smil z Letovic (ZDO 3, č. 65), ale lze předpokládat, že vesnice fungovala i před tímto datem. Navíc je $\mathrm{v}$ tomto prrípadě potřeba brát v potaz pouze rámcové datování nálezů získané archeologickým výzkumem, respektive obecný problém s menší chronologickou citlivostí keramického materiálu a s tím spojeným kolísáním datování i v řádech několika desítek let. Jak se tedy zdá, ZSV Mokronosy se nacházela podél Šardického potoka a ZSV Jarohněvice v místech tratí Kosteliska či Na Kostelisku a Louky od valů.

První zmínka o zaniklé středověké vsi Jarohněvice pochází z listiny Jindřicha Zdíka z roku 1141 (nově předatováno J. Bystřickým; v minulosti udáván rok 1131, viz Bistřický 1998), kdy celá ves náležela ke kostelu ve Spytihněvi, tehdy jednomu z církevních center jižní Moravy (CDB I, 121 č. 115). Tato zmínka je ale sporná, protože jsou pravděpodobně míněny Jarohněvice u Kroměříže. Tomu by nasvědčovalo i to, že zmíněná ves leží necelých $25 \mathrm{~km}$ od Spytihněvi. Již nesporná zmínka pochází z roku 1222, kdy je v Jarohněvicích vzpomínán kostel, respektive zdejší farář Adolf (CDB II, 228 č. 238). V roce 1286 je jako člen smírčí komise ve sporu mezi šardickým šlechticem Soběhrdem a mistřínským plebánem jmenován „plebanus de Gernowicz“ Rudger (CDM IV, č. 231). V roce 1349 prodává vdova po Ratmanovi Bonka polovinu Jarohněvic Smilovi z Letovic (ZDO, 3 č. 62-63) a druhou polovinu zapisuje Alšíku Kuželovi z Žeravic (ZDO, 6 č. 117). Páni z Letovic na své majetky i v Jarohněvicích vstupují do nedílu v roce 1360 (ZDO I, 35 č. 703). V roce 1408 prodává Hynek z Ronova a Letovic celou (!) vesnici s tvrzí, kostelem (tj. patronátem), dvorem a mlýnem Vítoslavu z Voděrad (ZDO, 279 č. 641). O čtyři roky později, tedy $\mathrm{v}$ roce 1412, prodává tyto majetky Vítoslav bratřím Ješkovi a Mikuláši z Újezda (ZDO, 312 č. 317). Vlastníkem Jarohněvic je po husitských válkách Jan Rybníček, ten zde v roce 1447 zapisuje věno své manželce Johance z Doloplaz (ZDO, 390 č. 490, 391 č. 505, 393 č. 531). Nejpozději v roce 1491 drží Jarohněvice Pernštejnové, protože v tomto roce jim panovník povoluje zvýšit hráze rybníka u Jarohněvic, což mělo poškodit majetky augustiniánského kláštera sv. Tomáše v Brně (AČ XVI, 398-399). Jako zaniklá ves (ale stojící tvrz) jsou Jarohněvice uváděny v roce 1492 (AČ XVI, 417, 427, 438, 461). V roce 1496 ovšem Vilém z Pernštejna malé panství prodává, Mokronosy jsou uváděny jako pusté, ale Jarohněvice nikoliv (AČ XVI, 506). Jarohněvický dvůr, nebo také Jaronovický dvůr, se v listinách objevuje až k roku 1576 (Nekuda 1961, 79). 
V roce 1927 byl v trati Kosteliska odkryt Juliem Kupkou půdorys kostela. O samotné akci se dochovaly jen kusé zprávy v dubňanské obecní a farské kronice. S myšlenkou velkomoravského stáŕí církevní stavby zde v roce 1962 provedli pracovníci mikulčické expozitury brněnského archeologického ústavu menší odkryv a průzkum okolí (Klanica 1963, 66). V místě odkryvu byla prozkoumána část destrukce větší kruhovité stavby (nejspíše se uvažovalo o kruhovém uzávěru apsidy) a 16 kostrových hrobů bez hrobové výbavy. Domněnka o velkomoravském stáří se nepotvrdila, protože keramický materiál z destrukce kostela byl datován do 12. až 14. století. O tom, jak vypadal samotný kostel, se zprávy různí. Pravděpodobně nejdůvěryhodnější je zápis z farské kroniky v Dubňanech, který kostel popisuje jako $20 \mathrm{~m}$ dlouhou a $9 \mathrm{~m}$ širokou stavbu z kamene a vypálených cihel menšího formátu, ukončenou půlkruhovou apsidou, která byla od kněžiště oddělena triumfálním obloukem. Zmíněné cihly se vyskytovaly i v místech zaniklého opevněného sídla na druhém břehu Kyjovky, což by mohlo naznačovat, že obě lokality mohly být postaveny ve stejné době. Podle nálezové situace je možné, že kostel vyhořel. Uvnitř a vně sakrální stavby bylo nalezeno velké množství lidských kostí a lebek, které pravděpodobně pocházejí z přilehlého hřbitova. Samotný půdorys kostela, sestávající z jedné hlavní lodi se zbytky obloukovité apsidy, je dnes dobře patrný na ortofotosnímku z roku 2015 a odpovídá nálezové situaci.

V trati Louky od valů, která se nachází na druhé straně Kyjovky, asi 400 m severozápadně od kostela, se nachází pozůstatky poměrně rozměrného opevněného sídla. V roce 1997 zde provedl M. Bálek letecký průzkum, při kterém byl v místech zaniklého sídla velice dobře patrný polygonální útvar tvořený světlejšími a tmavšími vícenásobnými liniemi, které byly interpretovány jako zbytky násypů a př́kopů (Bálek-Knechtová 1999, 392). Vnější příkopy, jejichž šiř́ka kolísá od ca 12 do $21 \mathrm{~m}$, jsou od sebe vzdáleny v nejširším rozestupu ca $170 \mathrm{~m}$. Navíc se zdá, že na jihozápadní straně byl příkop zdvojený. Uvnitř se nachází vnitřní př́íkop o šířce kolísající mezi ca 14 a $25 \mathrm{~m}$ a rozměrech ca $80 \times 75 \mathrm{~m}$, který obtáčí nepravidelný centrální pahorek o rozměrech ca $35 \times 67$ m. Jak uvádí M. Plaček (2001, 272-273), který poněkud poddimenzoval rozměry zaniklého opevněného sídla, okolo vnitřního prríkopu se obtáčí násep, který na jihu přechází v nepravidelné předhradí. $Z$ něj na jihozápadní straně vyčnívá obdélný výstupek, pravděpodobně pozůstatek po bráně. Po opětovném prostudování leteckých snímků se také zdá, že na severovýchodní straně se nachází další př́ikop s náspem. Zbytky vnitřního příkopu jsou i v omezené míře patrné na ortofotosnímcích z let 2005 a 2006. Oproti leteckým snímkům pořízeným M. Bálkem ovšem nelze na novějších ortofotosnímcích vlivem odlišných porostových podmínek rozeznat pozůstatky vnějších příkopů a ani místo s předpokládaným vstupem.

Severně, západně a jižně od kostela jsou na ortofotosnímcích z let 2009 a 2015 a na leteckém snímku od M. Bálka z roku 1997 dobře patrné porostové př́iznaky v podobě velkého množství menších a větších bodových a několika lineárních útvarů. Dva lineární porostové příznaky, jeden silnější a jeden tenčí, které prochází zaniklou vsí od severu k jihu, lze interpretovat jako pozůstatky zaniklé vodoteče a historické cesty. Obě tyto lineární struktury jsou zaznamenány na listech II. vojenského mapování z první poloviny 19. století. Další lineární porostový příznak se nachází jednak na jihu, kde se táhne paralelně s historickou vodotečí, a jednak na severu, kde ohraničuje intravilán vesnice ze severní strany. V tomto případě lze uvažovat o tom, že se jedná o zbytky ohrazení ve formě př́ikopu. Tomu by odpovídal i fakt, že mezi domnělým příkopem a kostelem se nachází velké množství bodových porostových příznaků, které lze interpretovat jako sídlištní objekty různého charakteru. Jak se prozatím podle leteckých snímků zdá, objekty toto ohraničení respektují a nepokračují dál. Další sídlištní objekty se koncentrují po obou stranách jasně vymezeného stř̌edového pásu bez porostových příznaků, který se táhne od zbytků kostela směrem na severozápad. V severozápadní části zaniklé vsi je šíře pásu $30 \mathrm{~m}$, ale směrem na jihovýchod se pozvolna rozšiřuje a v místech kostela dosahuje šiřky až $60 \mathrm{~m}$. Na leteckých snímcích je dále patrné, že jeho středem prochází tmavší pruh, který pás rozděluje na dvě části. Následně po leteckém průzkumu v roce 1997 byly na lokalitě provedeny povrchové sběry, díky nimž byla získána keramika z 13.-15. století (Bálek-Knechtová 1999, 392). 
Podle leteckých snímků se tedy zdá, že zaniklá ves Jarohněvice se nacházela na rozmezí tratí Kostelisko a Louky od valů. Keramický materiál získaný ze sondážního odkryvu v roce 1962 (Klanica 1963, 66) a povrchového průzkumu z konce 90. let 20. století (Bálek-Knechtová $1999,392)$ lze souhrnně časově zařadit do rozmezí od 12. do 15. století, což koreluje se zmínkami z písemných pramenů. Vesnice se táhla ca $420 \mathrm{~m}$ od opevněného sídla směrem na jihovýchod, kde se nacházel kostel. Zda tímto směrem vesnice dále pokračovala, nelze na základě dostupných informací rozhodnout (dále je les). Stejně tomu je i na jihu. Že může tímto směrem osídlení pokračovat, by mohlo naznačovat i to, že v roce 1910 byly v blízké trati Nadýmák vykopány zbytky staviva a lidské lebky (Hlavinka et al. 1926, 187). Otázkou je, zda se nejedná o nějaké další pozůstatky po lidské činnosti, které nemají s vesnicí nic společného, anebo došlo opět k omylu v tratových názvech, a tyto nálezy pochází z místa, kde stával kostel. Nálezy lidských lebek by svědčily pro druhou možnost. Na leteckých snímcích je dále patrné, že středem delší osy vesnice procházela náves, která pravděpodobně byla podél delší osy rozdělena na dvě části. Náves se směrem na východ rozšiřovala a v místech nejširšího úseku stál kostel se hřbitovem. Středem kratší osy vesnice procházela vodoteč, respektive tzv. mlýnský náhon. Ten vedl podle historických map k již nefunkčnímu mlýnu, jehož budovy dodnes stojí u hráze Jarohněvického rybníka. Severozápadním okrajem vesnice prochází dnes již regulované koryto Kyjovky, která narušuje zbytky opevněného sídla. Jak se podle leteckých snímků zdá, zaniklá ves mohla být alespoň z jedné - severní - strany ohrazena př́kopem. Ohrazení vesnice je ovšem otázkou pro další zkoumání. V roce 1892 totiž dubňanský farář V. Oharek píše (1892, 323-324), že trat' Kostelisko byla podle vzpomínek starých sousedů ještě před 40-50 lety, tedy někdy mezi lety 1840-1850, obehnána jakoby „valem a náspem“ a místo sloužilo jako pastva pro koně. To vše bylo později rozoráno a pastviny byly přeměněny na pole. Vzhledem $\mathrm{k}$ tomu, že je ve vzpomínkách zmíněna trat' Kostelisko, nabízí se otázka, zda tyto „valy a náspy“ lze ztotožnit s místem, kde se nacházela vesnice, a tím pádem tak potvrdit její ohrazení (a uvažovat tak nepřímo i o př́ikopech). Zdá se však, že nikoliv. Dubňanští „pamětníci“ spíše zaměnili tratová jména a tyto „,valy a náspy“ je nutné hledat na místě, kde se nachází opevněné sídlo, tedy v trati Louky od valů. Tak jako např́iklad nověji M. Plaček (2001, 272-273), anebo v minulosti I. L. Červinka, který uvádí, že ještě v roce 1928 lze „dobře rozeznat kopeček a kolem něj násyp v prưměru asi 60 kroků, znatelný okrouhlý přikop jest už zasut" $(1942,35)$. Ovšem toto místo ztotožňuje s mokronoskou tvrzí, která je v písemných pramenech připomínaná v roce 1408 (ZDO, 279, 284 č. 641, 716). K objasnění celé situace by mohl pomoci plošný geofyzikální průzkum, který by jednak definoval zbylé hranice intravilánu zaniklé vsi, popřípadě vyjasnil její vnitřní strukturu, a jednak přispěl k dalším informacím ohledně půdorysného uspořádání zaniklého opevněného sídla. Navíc by mohl identifikovat další potenciální archeologické struktury v širším okolí zaniklé vesnice.

Koválov (k. ú. Žabčice, okr. Brno-venkov; obr. 4:4)

J. Unger s jistou rezervou uvádí (1994, 10), že majitelem a i možným lokátorem Koválova mohl být jistý Bořimír z Koválova. Ten byl uveden jako svědek na listině z roku 1173, s níž Vilém z Pulína založil dolnokounický klášter (CDB I, č. 400, 415-417). Jedná se o falzum, které vzniklo někdy před rokem 1276, ale uvedení svědkové byli osoby žijící v rozmezí let 1218-1240 (Dušková 1973). První nezvratný důkaz o existenci Koválova je až Přemyslovo potvrzení fundace kláštera ve Žd’áře nad Sázavou z roku 1252, kde se objevuje trojice bratrů: Bohuš z Koválova (Bohusche de Cowal), Jan z Višňového a Matěj (Matheus). Zřejmě nejmladší z bratrské trojice je uváděn jako vlastník Koválova mezi roky 1259 a 1269 (CDB V/1, 284 č. 177, 523-524 č. 351-352; CDB V/2, 107 č. 545, 196 č. 600). Další zmínka o Koválově je až z roku 1307, a to v souvislosti s místním farním kostelem, který odváděl desátky klášteru v Dolních Kounicích (CDM VI, 5 č. 6). Následující zmínka pochází z 11. června 1314, kdy brněnský purkrabí jménem Jan z Meziříčí svědčí, že dostal ves a tvrz Koválov na doživotí od dolnokounického kláštera, přičemž Jan z Meziříčí tuto ves obnovil (MSL I, 84-85 č. 51). 
V roce 1351 zde získává Jindřich z Ledce dvě popluží a šest hřiven ročního platu (ZDB I, 14 č. 18). V 60. letech 14. století je Koválov uváděn jako městečko, a to v souvislosti s Hansem z Weitmile, který prodává 14 lánů Přibíkovi z Polánky (ZDB I, 158 č. 57). V roce 1390 prodává Přibík těchto 14 lánů Hanušovi z Ledce, který na ně a patronát kostela vstupuje do spolku s Ondřejem z Nechvalína (ZDB I, 168 č. 663). Majetky v Koválově se dostávají do markraběcích rukou a v roce 1398 je dostává Filip ze Svojanova (ZDB I, 226 č. 204). Zároveň je Čeněk z Nechvalína v roce 1409 zapisuje své sestře, která na ně vstupuje do nedílu s manželem Erhartem ze Skal (ZDB I, 283 č. 38-39). Po smrti Erharta prodává v roce 1447 stejné majetky Dítěti z Kelčic (ZDB I, 370 č. 622). Posledním vlastníkem vesnice je od roku 1493 Ladislav z Boskovic, který ji v roce 1510 prodává již jako pustou Vilémovi z Pernštejna (Nekuda 1961, 98-99).

Zaniklá vesnice se nachází asi 1,8 km jihozápadně od středu obce Žabčice na rozmezí tratí Čtvrtky a Padělky v nadmořské výšce ca $200 \mathrm{~m} \mathrm{n}$. m. Na lokalitě byly v minulosti provedeny povrchové sběry (Unger 1972) a v severovýchodní části vesnice byl odkryt jednolodní kostel s obdélným půdorysem, polygonálním presbyteriem a menším pohřebištěm (Měřínský-Unger 1983, 1987). V 80. letech 20. století byl v několika sezónách proveden archeologický výzkum opevněného šlechtického sídla typu motte, které se nacházelo v západní části zaniklé vsi na místě označovaném jako Kulatý kopec (Unger 1989; 1994). V letech 1993 a 1994 byl nad lokalitou proveden M. Bálkem letecký průzkum (obr. 3), který díky vhodným porostovým př́iznakům odhalil v jižní, západní a severní části průběh několika linií, které byly interpretovány jako pozůstatky př́ikopů
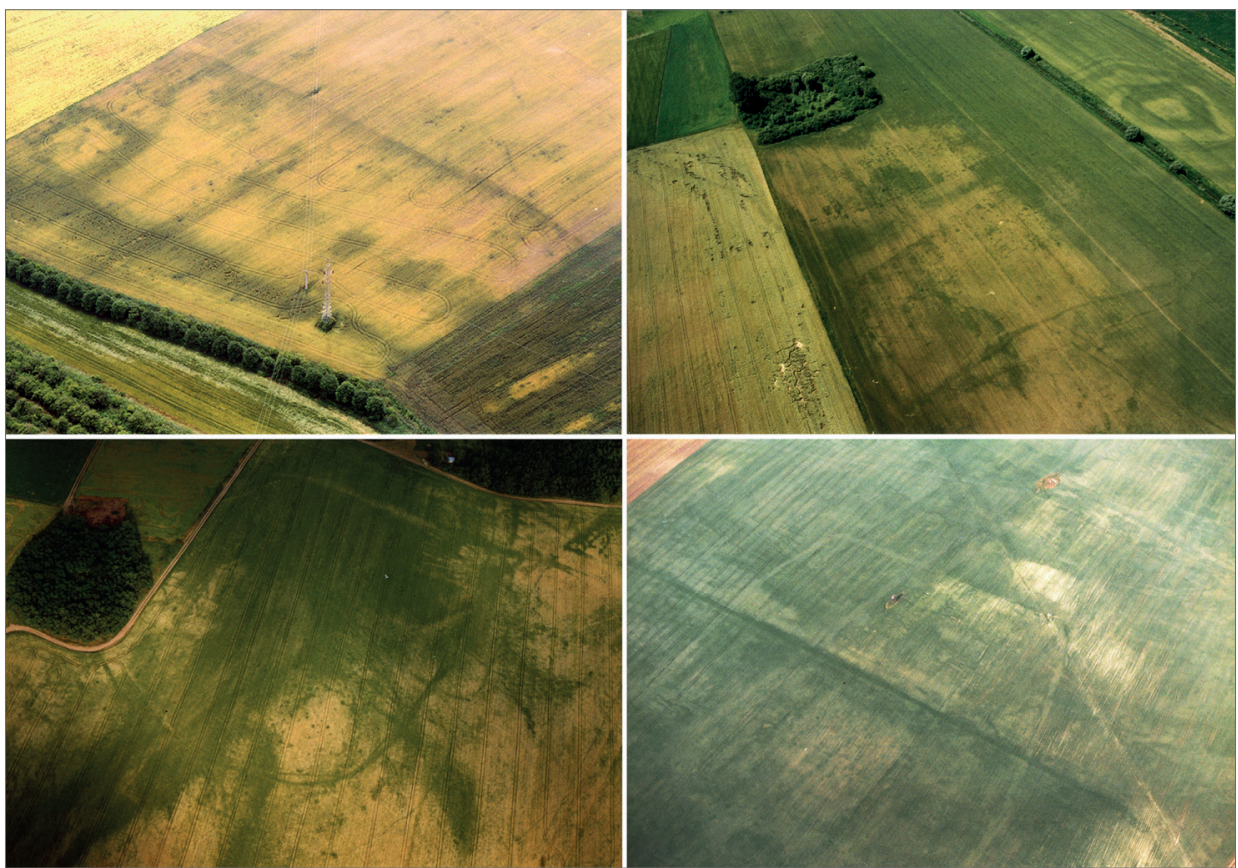

Obr. 3. Letecké snímky pořízené Miroslavem Bálkem. Nahoře vlevo pohled na ZSV Divice (k. ú. Brumovice; okr. Břeclav) od severozápadu; nahoře vpravo ZSV Jarohněvice (k. ú. Dubňany; okr. Hodonín) od severovýchodu; dole vlevo ZSV Koválov (k. ú. Žabčice; okr. Brno-venkov) od severozápadu; dole vpravo ZSV Hroznětice (k. ú. Dobré Pole; okr. Břeclav) od jihozápadu. Zdroj Archiv ARÚ Brno.

Abb. 3. Von Miroslav Bálek gemachte Luftbildaufnahmen. Oben links Blick auf die mittelalterliche Dorfwüstung Divice (Katastergebiet Brumovice; Bezirk Břeclav) von Nordwest; oben rechts mittelalterliche Dorfwüstung Jarohněvice (Katastergebiet Dubňany; Bezirk Hodonín) von Nordost; unten links mittelalterliche Dorfwüstung Koválov (Katastergebiet Žabčice; Bezirk Brno-Land) von Nordwest; unten rechts mittelalterliche Dorfwüstung Hroznětice (Katastergebiet Dobré Pole; Bezirk Břeclav) von Südwest. Quelle Archiv des Archäologischen Instituts Brno. 
a žlabů minimálně dvou fází ohrazení vesnice. V severní části byl průběh ohrazení potvrzen i geofyzikální prospekcí. Během leteckého průzkumu se podařilo zachytit i zbytky vnitřní zástavby v podobě menších i větších sídlištních objektů (Bálek-Unger 1996, 432-433). Výsledky leteckých prospekcí potvrzují ortofotosnímky z let 2009 a 2015, na kterých je mimo jiné jasně patrné ohrazení z jižní a západní strany v podobě asi $2 \mathrm{~m}$ širokého příkopu a několika užších lineárních útvarů - pravděpodobně menších žlabů. Pole v severní části vesnice byla v nedávné době osázena vinohrady, což zde znemožnilo sledovat jakékoliv další porostové př́iznaky.

Na základě leteckého průzkumu a novějších ortofotosnímků je zřejmé, že ZSV Koválov byla ohrazena př́ḱkopy a žlaby, a to pravděpodobně v několika fázích. Otázkou zůstává chronologie jednotlivých fází ohrazení a jeho celková velikost, protože v jihovýchodní části lokality je další průběh ohrazení kvůli lesnímu pokryvu nečitelný. Celý ohrazený areál pak mohl zabírat plochu minimálně 5 ha, pravděpodobně však až 14 ha.

Starý Mistř́n (k. ú. Mistřín, okr. Hodonín; obr. 4:5)

Zaniklá ves „Starý“ Mistř́ín se v písemných pramenech poprvé objevuje v listopadu 1228 jako majetek velehradského kláštera v podobě Mistrin (CDB II, 319-323 č. 321). V roce 1286 je znám místní farář a na počátku roku 1365 je v papežské listině zmíněn místní farní kostel (MV III, 258 č. 432). Změnu vlastníka přinesly až husitské války. Velehradský klášter byl v lednu 1421 vypálen husity a dočasně zanikl. Jeho majetky využil Zikmund Lucemburský k financování války a zastavoval je svým šlechticům. Snad již ve 20. letech 15. století byl zastaven i Mistř́n, zřejmě Janu z Džbeř́ikovi z Hartvíkovic (u Náměšti nad Oslavou), který měl v erbu ptáka, zřejmě kosa. Mistřín zcela určitě drží od konce 50. let 15 století jeho syn Ctibor a později Jan, který žije ještě $\mathrm{v}$ roce 1500 . O něm je zmínka pocházející z roku 1489, kdy se olomoucký klášter prostřednictvím Jana Berky z Dubé a z Lipé na Šternberce zaručuje, že vloží do olomouckých zemských desek Janu Džbeříkovi z Mistřína držbu sedmi a půl lánu ve Skoronicích, které Džbeřík odkoupil od kláštera před pěti lety (Zemek-Turek 1983, 293 č. 448).

Poručníkem dětí Jana byl Zikmund z Ludanic, v roce 1523 Mistřín získávají Heralt a Vilém Kuna z Kunštátu, ovšem již nikoliv jako zástavu, ale jako svobodný majetek (Hurt 1934, 103; Pilnáček 1930, 197; LCS, 122 č. 572). Zřejmě během česko-uherských válek byl Starý Mistřín zničen, k obnovení vesnice došlo v jiné poloze před rokem 1539, kdy je již zmiňován Nový Mistřín (Hurt 1970, 391). Ten byl 1. července 1605 při tzv. Bočkajově povstání opět vypálen. Zcela zničen byl Nový Mistř́n někdy během třicetileté války, která se Evropou prohnala v letech 1618-1648. Kolem roku 1656 byla obec Mistřín vystavěna potřetí, a to na současném místě.

Lokalita se nachází při západním okraji obce Mistřín v trati Staré Mistřiny, severně od silnice Mistřín-Šardice. Nadmořská výška na lokalitě kolísá od ca 195 do $200 \mathrm{~m} \mathrm{n}$. m. Na ortofotosnímcích z let 2009 a 2015 jsou v místech zaniklé vesnice dobře viditelné lineární struktury, které je možné interpretovat jako 2-3 m široké př́íkopy. Nejlépe jsou patrné na severní a jihozápadní straně vsi. V severozápadní části ohrazeného areálu je na ortofotosnímcích dobře patrné nároží. Na severovýchodní straně je průběh př́íkopu z části narušen polní cestou. Kvůli dnešní zástavbě není viditelné ohrazení na jihovýchodní straně vesnice, ale je možné, že kopírovalo průběh ulice Šardická. Pokud tomu tak bylo, celý ohrazený areál měl rozměry ca $540 \times 200 \mathrm{~m}$. Lokalita se nachází na svazích mírného údolí, které se svažuje jihovýchodním směrem. Na ortofotosnímcích z roku 2015 se středem lokality táhne ve směru severozápad-jihovýchod tmavší lineární pás, který se zhruba ve středu lokality kříží s druhým tmavším lineárním pásem jdoucím ze severozápadního směru. Jedná se o dvě zaniklé komunikace, které jsou dobře zřetelné na archivním snímku ČÚZK z roku 1953. Obě cesty jsou také vyznačeny jak na mapě II. vojenského mapování, tak i na indikační skice a na císařských povinných otiscích map stabilního katastru z roku 1825 . Na ortofotosnímku z roku 2015 je dále patrné, že po obou stranách středové komunikace se nachází v podobě tmavějších skvrn velké množství větších i menších plošných porostových příznaků, které lze interpretovat jako pravděpodobné pozůstatky sídlištních objektů. Další zaniklá cesta, 
která je vyznačena i na výše zmíněných historických mapách, je viditelná v jihozápadním rohu ohrazeného areálu.

Podle leteckých snímků je tedy zřejmé, že ZSV „Starý“ Mistřín byla v minulosti nejméně ze tří stran ohrazena, a to minimálně jedním př́kopem. Celý areál o rozloze 10,1 ha je svým rozsahem, ohrazením a orientací podobný jiné zaniklé vesnici, a to ZSV Opatovice, která se nachází asi $20 \mathrm{~km}$ jihozápadním směrem. Ta, stejně jako ZSV „Starý“ Mistřín, zanikla někdy $\mathrm{v}$ druhé polovině 15 . století.

Na podzim roku 2016 byl v severní části vesnice proveden nedestruktivní geofyzikální průzkum za pomoci magnetometru, který jednak potvrdil průběh př́ikopu jak na severozápadní, tak i na severovýchodní straně zaniklé vesnice, jednak poodhalil i vnitřní zástavbu uvnitř ohrazeného areálu. Díky magnetometrické prospekci se také podařilo identifikovat velké množství sídlištních objektů, které se koncentrují po obou stranách zaniklé cesty. Ta, jak už bylo zmíněno výše, prochází středem celého areálu od severozápadu k jihovýchodu a její průběh je dobře patrný jak na leteckých kolmých snímcích, tak i ve výsledcích geofyzikálního měření. Podle dosavadních výsledků se zdá, že vesnice mohla být i nějakým způsobem vnitřně členěna.

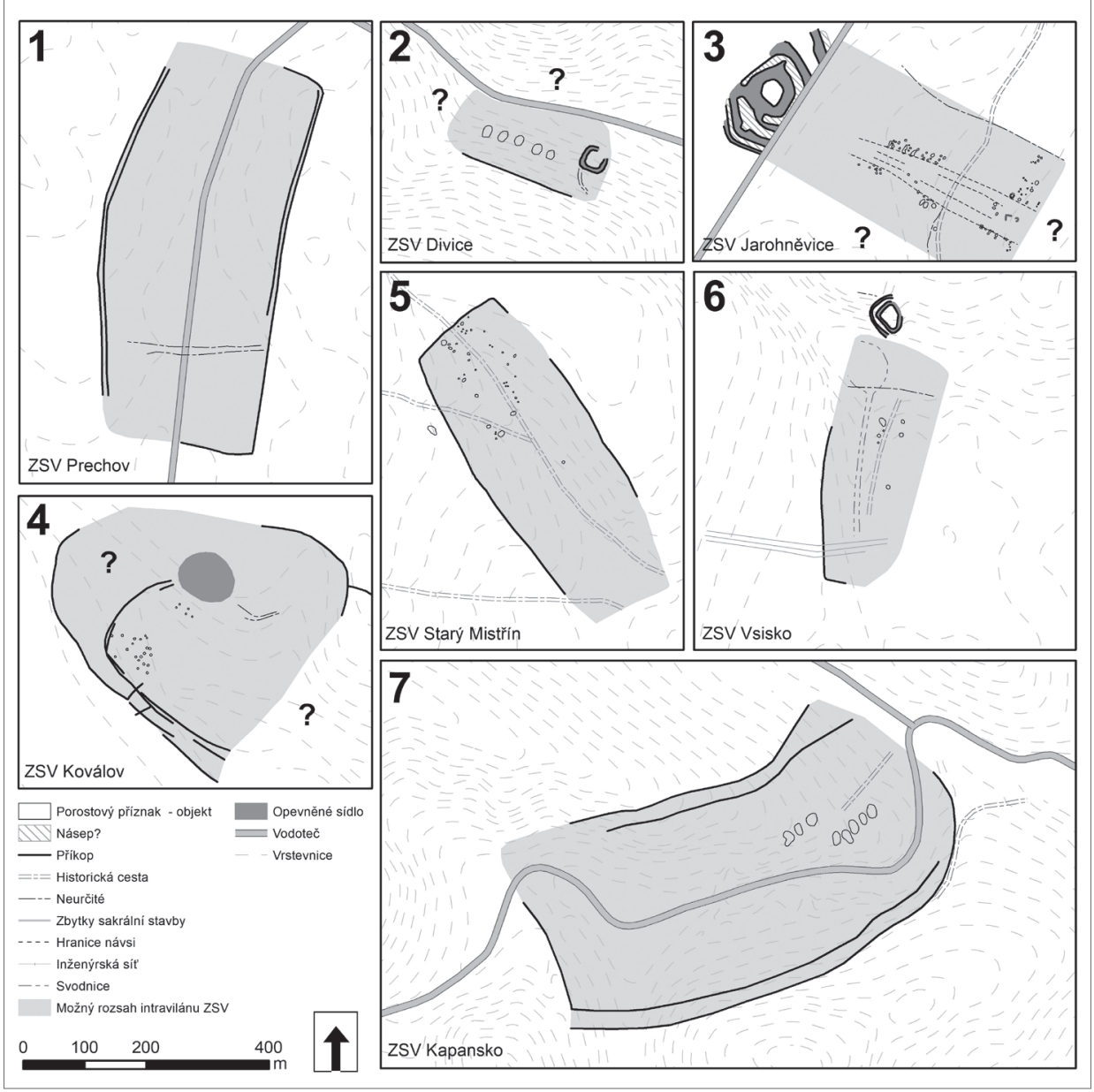

Obr. 4. Interpretace porostových příznaků na zaniklých středověkých ohrazených vesnicích.

Abb. 4. Interpretation der Vegetationsmerkmale an mittelalterlichen umfriedeten Dorfwüstungen. 
Vsisko (k. ú. Dolní Bojanovice, okr. Hodonín; obr. 4:6)

Zaniklá středověká vesnice Vsisko stávala ve stejnojmenné trati asi 1,8 km severovýchodně od středu obce Dolní Bojanovice. Lokalita se nachází v mírném svahu na dlouhodobě obdělávaném poli v nadmořské výšce ca $181 \mathrm{~m} \mathrm{n}$. m. Její původní název se patrně nedochoval, takže pusté místo bylo označováno už jen jako Vsisko. V urbáři panství hodonínského z roku 1691 je poznamenáno: „Dédina Vsisko jsouc od množstvi let pustá a nejsouc naděje k osazení pro ouzkost živností a pasunkưv, byla rozdělena mezi sousedni vsi.“ Pozemků užívali poddaní a platili desátou kopu jak z jařin, tak i z ozimů (Nekuda 1961, 146). Podle V. Nekudy se jednalo o ves Kreutz, ale tato domněnka byla L. Janem odmítnuta a název byl přiřazen Mutěnicím (Jan-Štěpánek 2002). J. Unger se domnívá, že by se mohlo jednat o zaniklou ves Kapansko (jmenovanou i jako Kapanice; Unger-Šedo-Knápek 2017, 230-231), respektive o její starší vysazení s tím, že vesnice mohla být v průběhu času přesunuta mezi Čejkovice a Mutěnice. To by mohl naznačovat pomístní název trati Nové Kapánsko, v níž se nachází zbytky další zaniklé vesnice (viz následující kapitola Kapansko).

V roce 2013 byl dálkovým průzkumem Země identifikován asi $120 \mathrm{~m}$ severně od vesnice v trati Zámčisko kruhový areál o průměru ca $25 \mathrm{~m}$, který je tvořen dvěma příkopy o šířce ca 3-6 m. Na východní straně je průběh příkopů narušen bývalou pískovnou, na jižní straně polní cestou. Podle všeho se jedná o pozůstatek neznámého drobného opevněného sídla, na kterém byla $\mathrm{v}$ roce 2013 provedena i geofyzikální prospekce s pomocí magnetometru (Dresler-Tencer 2016), která potvrdila samotný průběh př́ikopů. Uvnitř a vně ohrazeného areálu se navíc podařilo identifikovat několik plošných anomálií, interpretovaných posléze jako pozůstatky po sídlištních aktivitách.

Ohrazení samotné vsi je dobře patrné již na nejstarších leteckých snímcích, pořízených na sklonku let 40. a na počátku let 50. a 60., na kterých je dobře viditelný několik metrů široký remízek s mírně vzrostlou křovinatou vegetací. Táhne se po západní straně zaniklé vsi směrem na sever, kde se vytrácí s hranicí lesa zvaného Dolní Kapansko. Na jihu vytváří nároží, které se stáčí směrem na východ. Zde mizí pod asfaltovou cestou směrem na Mutěnice, která ohraničuje areál z východní strany. Na leteckém snímku z roku 1938 je dobře vidět, že remízek odděluje dva na sobě nezávislé systémy polních parcel - uvnitř a vně ohrazeného areálu. Podle snímku z roku 1953 se ovšem zdá, že menší pole uvnitř ohrazeného areálu už byla scelena, kdežto pole v okolí zaniklé vesnice jsou stále rozdělena na menší parcely. Jinak je tomu již na snímku z roku 1963, kde jsou i okolní pole sjednocena do větších lánů. Stále je však na leteckém snímku patrné ohraničení zaniklé vsi z její západní a jihozápadní strany. Někdy po tomto roce muselo dojít k jeho rozorání a ke sjednocení polí vně a uvnitř areálu zaniklé vesnice. Na novějších ortofotosnímcích jsou pozůstatky ohraničení patrné na snímcích z roku 2009, kde se projevují asi 3-4 m širokým tmavým pásem porostových příznaků.

Středem vesnice prochází dva lineární útvary. Západnější, excentricky posazený, je občasnou svodnicí. To dokládá ortofotosnímek z roku 2003, z nějž je zřejmé, že po jarních deštích je tudy splachována půda severním směrem a vytváří kruhovitý útvar splavených sedimentů. Východně položený lineární útvar lze na základě studia historických map a geofyzikální prospekce interpretovat jako pozůstatek po zaniklé historické komunikaci, která procházela stř̌edem delší osy zaniklé vsi. Okolo identifikované komunikace se koncentrují porostové příznaky v podobě větších i menších tmavších plošných i bodových útvarů, které lze interpretovat jako pozůstatky sídlištních objektů. Jejich přítomnost byla potvrzena i plošnou magnetometrickou prospekcí uskutečněnou v roce 2016 (Vágner et al. 2018). Jižní a východní část vesnice je narušena průběhem inženýrských sítí, které jsou částečně viditelné i na leteckých snímcích. Severní ohraničení zaniklé vsi je sporné. Na snímku od Zeměměřického úřadu z roku 2009 v kombinaci se snímkem společnosti GEODIS z téhož roku (dostupný na GoogleEarth) lze pozorovat v severní části areálu prríčný pruh probíhající ve směru východ-západ. Geofyzikální průzkum však žádné zbytky ohrazení nezachytil. Proto lze uvažovat o dvou pravděpodobných variantách. Bud' toto severní 
ohrazení kopíruje průběh dnešní polní cesty vedoucí z lesa Dolní Kapansko směrem k asfaltové komunikaci, podobně jako tomu může být na východní straně lokality, nebo se toto ohrazení nachází necelých 100 metrů severně od polní cesty, a to v těsné blízkosti severního okraje drobného šlechtického sídla. Tomu může napovídat stav zachycený na II. vojenském mapování a císařských otiscích stabilního katastru, kde je dobře patrná hranice mezi pravděpodobným vnitřním areálem zaniklé vsi (v té době patrně sloužícím jako pastviny) a okolními polnostmi. Zbytky této hranice jsou ještě patrné i na leteckých snímcích z let 1938, 1953 a 1963 (shrnuto Vágner et al. 2018).

Kapansko (k. ú. Mutěnice, okr. Hodonín; obr. 4-7)

Zaniklou vesnici Kapansko (často uváděnou i jako Kapanice) potvrzuje papežská listina z roku 1235 jako vlastnictví tišnovského kláštera, který byl založen nedlouho předtím (CDB III/1, 150 č. 120). V roce 1257 získává třetinu vinného desátku z Kapanic kostel v nedalekém Čejči (CDB, 211 č. 131). Další zmínka je až z roku 1415, ve kterém je zmiňována jistá Kateřina, dcera Dětřicha z Kapanic (ZDB, 297 č. 135). V roce 1576 prodává Čeněk z Lipé již pustou ves Aleně ze Žerotína. Hodonínský urbář z roku 1691 o ní píše, že zanikla v důsledku válek (Nekuda 1961, 97). I přesto, že je Kapansko blíže Čejkovicím, po zániku vesnice připadly parcely a podstatná část polních tratí Mutěnicím. Plocha zaniklé vesnice byla postupně rozdělena mezi obyvatele Mutěnic a většina parcel byla převedena na louky. Díky tomu se zde až do 70. let 20. století dochovaly půdorysy bývalých stavení, jejichž pozůstatky jsou v jihozápadní části severní poloviny vesnice zřejmě zaznamenány nejen na mapě II. vojenského mapování, ale i na ortofosnímcích.

Lokalita se nachází po levé straně silnice z Mutěnic do Čejkovic na rozmezí tratí Hrubé Padělky a Nové Kapánsko, necelé 2,3 km východně od středu obce Čejkovice. Rozkládá se na úbočích výrazného údolí, jehož středem prochází jednak bezejmenná vodoteč, která se asi 400 m východně od lokality vlévá do Mutěnického potoka, jednak polní cesta, která vede k východnímu okraji Čejkovic. Cesta je vyznačena na II. vojenském mapování a její starší průběh je patrný v podobě tmavějšího pásu vegetace i na ortofotosnímku z roku 2005 ve východní části lokality. Díky svažitosti terénu kolísá nadmořská výška lokality od 195 do $210 \mathrm{~m} \mathrm{n}$. m.

Na ortofotosnímcích z let 2005, 2006, 2009 a 2015 je na severozápadní a jihovýchodní straně údolí dobře patrný dvojitý 3-4 m široký tmavý pás. Ten lze interpretovat jako pozůstatky ohrazení ve formě př́kopu, jehož jednotlivé linie mají rozestup v průměru $20 \mathrm{~m}$. Na jihozápadní straně zaniklé vsi se vnitřní linie př́kopu prudce stáčí k severozápadu, kde se její průběh dále vytrácí. Průběh vnější linie je v těchto místech nezřetelný. Naopak tomu je na severovýchodní straně ohrazeného areálu, kde se vnější linie př́ikopu stáčí v pozvolném oblouku k severozápadu. Průběh vnitřní linie je v těchto místech nezřetelný. Na severní straně úbočí není patrné ani jedno nároží. Dvojice př́ikopů je zde kvůli porostovým př́znakům viditelná pouze v podobě dvou $500 \mathrm{~m}$ dlouhých tmavých pásů táhnoucích se od jihozápadu na severovýchod, kde jsou př́kopy přerušeny silnicí Mutenice-Čejkovice. I přesto lze díky dostupným informacím stanovit přibližnou velikost vesnice, která činila ca $690 \times 360$ m a zabírala plochu 23,5 ha. Kromě dvou př́kopů byl okolo vesnice vybudován i hliněný násep. Jednak bylo potřeba někam uložit vykopanou zeminu z př́ikopů a jednak pro to máme nepř́mý doklad v názvu trati $\mathrm{Na}$ valech $\mathrm{v}$ jižní polovině zaniklé vesnice, který je zřejmě až z druhé poloviny 20. století.

V severozápadní části ohrazeného areálu je na ortofotosnímcích z let 2005, 2006, 2009, 2012 a 2015 patrná lineární struktura v podobě asi $7 \mathrm{~m}$ širokého a $130 \mathrm{~m}$ dlouhého tmavého pásu. Mohlo by se jednat o zbytek staré komunikace, která procházela vesnicí. Tomu by nasvědčovaly i náznaky struktur, které jsou patrné v jejím okolí, respektive v celé severní části ohrazeného areálu. Jedná se o několik obdélných porostových příznaků o rozměrech v průměru $11 \times 12 \mathrm{~m}$. Nejvíce jsou patrné na severovýchodní straně zaniklé vesnice, ale jejich pokračování lze díky dalším porostovým prŕźzakům tušit i dál směrem na jihozápad. Tomu by nasvědčoval i stav zachycený na II. vojenském mapování. 
V roce 1972 bohužel došlo na lokalitě k necitlivým terénním úpravám a definitivnímu zničení viditelných pozůstatků vesnice. Předtím zde byly dokonce ještě patrné půdorysy domů a propady lochů - sklepů, které byly již v minulosti zaznamenány na mapách z počátku 19. století.

Topolany (k. ú. Vranovice, okr. Brno-venkov; obr. 5:8)

Zaniklá stř̌edověká vesnice Topolany se nachází asi 1,6 km severozápadně od středu obce Vranovice v trati Teplansko či Na Teplanech, kde je dlouhodobě obdělávané pole. Lokalita se nachází v nadmořské výšce ca $195 \mathrm{~m}$ n. m., a to na mírném svahu obráceném k jihovýchodu. Na úpatí svahu je dodnes patrná úžlabina, kterou původně protékal potok. V její severní části prochází ve směru jihovýchod-severozápad polní cesta.

První zmínka o vsi pochází z roku 1257, kdy z topolanských osmi lánů potvrzuje olomoucký biskup Bruno desátky přibickému kostelu (CDB V/1, 206-207 č. 128). O tyto desátky se později vede spor mezi farou v Přibicích a klášterem Dolních Kounicích. Spor je urovnán v prosinci 1292 (MSL I, 42-44 č. 20). Vlastník Topolan je znám z roku 1358, kdy polovinu vsi držel brněnský měštan Jan Eberhard a jeho syn Mikuláš, kteří vstupují do spolku s Dětřichem Mořicovým, který vlastnil Vlasatice (ZDB, 33 č. 287). V roce 1369 se uvádí v majetku brněnských měštanů Jana a Bernarda, kteří byli taktéž jeho syny. Ti ovšem vedou spor o vesnici s kounickým klášterem. Spor rozhoduje pražský arcibiskup, a to tak, že za 18 let mají oba bratři vrátit vesnici klášteru (MSL I, 156-159 č. 99). Toto rozhodnutí potvrzuje následující rok i markrabě Jan Jindřich (MSL I, 161-162 č. 101). Ve vkladu dědictví Kounicům z roku 1537 se ves uvádí již jako pustá. V roce 1574 náležela $\mathrm{k}$ panství pršticko-vlasatickému a pole zaniklé vsi obdělávali poddaní z Vranovic (Bálek-Unger 1996, 432; Hosák 1967, 43; Nekuda 1961, 114).

V roce 1970 bylo na lokalitě $\mathrm{v}$ rámci melioračních prací narušeno několik desítek sídlištních objektů. Na základě toho byl proveden záchranný archeologický výzkum, který doložil existenci vesnice od první poloviny 13. do počátku 15. století (Michna-Unger 1972; Unger 1974, 28-29; 1975, 59; 1984). Daleko zajímavější zjištění přišlo až s leteckou prospekcí uskutečněnou M. Bálkem v roce 1994 (Bálek 1997, 311). Díky ní se podařilo v okolí vesnice zachytit přibližně 3 m širokou linii, která vymezovala šestiúhelníkový prostor o velikosti asi 6 ha (obr. 7). Interpretována byla jako př́íkop. V západní a v severní části byla linie přerušena, což by mohlo naznačovat místa se vstupy do areálu vesnice. Kromě vnějšího ohrazení vesnice se přibližně uprostřed areálu vyrýsoval obdélný útvar o rozměrech asi $35 \times 25 \mathrm{~m}$ obklopený dvojitou linií porostových př́iznaků v podobě tmavších pásů, opět interpretovaných jako pozůstatky po ohrazení ve formě př́ikopů. Vnější prŕíkop byl široký 5-6 m, vnitřní 6-7 m. Útvar byl interpretován jako pozůstatek neznámého menšího opevněného sídla. Jeho datování je však problematické, protože se nelze oprrít o žádné písemné prameny ani šlechtický predikát (Bálek-Unger 1996, 432-434; Matějíčková 2006, 243). Kvůli pravidelnému půdorysu je však prozatím možné uvažovat o jejím založení v průběhu první poloviny 14. století. Co se týče samotného příkopu, lze s ohledem na seříznutí vystupujících částí (tzv. mezilehlého valu) předpokládat, že př́ikopy měly šířku 10-12 m (Plaček 2001, 642). Vymezení ohraničeného areálu je dobře patrné i na císařských povinných otiscích stabilního katastru z roku 1825 , kde je polygonální areál vyznačen zelenou barvou, a proto se lze domnívat, že se zde v té době nacházely pastviny. O trochu jiná situace je zachycena na Katastrální mapě evidenční Moravy a Slezska z roku 1876. Okolní polnosti stále respektují ohraničení areálu, ale jeho vnitřní plocha už je rozdělena na množství menších parcel. Vnější ohraničení a vnitřní parcelace areálu je dobře patrná i na archivních leteckých ortofotosnímcích ČÚZK z let 1938 a 1947.

Hroznětice (k. ú. Dobré Pole, okr. Břeclav; obr. 5:9)

Zaniklá vesnice se nachází ve výběžku katastrálního území Dobré Pole asi 2,7 km severně od středu obce. Lokalita je situována v rovinatém terénu v nadmořské výšce přibližně $210 \mathrm{~m} \mathrm{n}$. m. První zmínka o vsi Hroznětice pochází z roku 1351, kdy je součástí drnholeckého panství a v této 
době náleží Vartenberkům (ZDB, 15 č. 32). V roce 1368 je celé panství postoupeno markraběti Janu Jindřichovi (ZDB, 79 č. 157-158). V 90. letech je celé panství zastaveno nejdříve hraběti z Hardekku a později Lichtenštejnům. Podle lichtenštejnského urbáře z roku 1414 zde bylo 53 osedlých, z toho 1 dvojlán, 13 lánů, 32 pololáníků a 7 čtvrtláníků (13 celoláníků, 32 pololáníků a 6 dvorů dle Nekuda 1961, 95). Dále se zde nacházely dvě brány, které obsluhovali čtyři čtvrtláníci. Podle písemných pramenů víme, že místní rychtář, který ve vsi vlastnil výše zmíněný dvojlán, měl k dispozici pro roboty dva podsedky, sám ještě vlastnil půl lánu v zaniklé vesnici Holanice. Ta se nacházela asi $5 \mathrm{~km}$ západně od Hroznětic v trati Holenické pole (k. ú. Drnholec). Ve vsi byla dále louka s názvem Wulfin a vinohrady (Bretholz 1930, 127, 130). Stejně jako řada vsí na drnholeckém panství i Hroznětice zanikly pravděpodobně někdy ve 20. letech 15 . století (Bálek-Unger 1996, 431). Pustými se jmenují až v roce 1578 (Nekuda 1961, 95).

V minulosti byl problém s přesnou lokalizací Hroznětic. K roku 1613 se u Dobrého pole uvádí vinohradní hora Rosentyc (Hosák 1967, 46; Nekuda 1969), která udávala přibližnou polohu lokality. Ta se pod dnešním názvem Růžová hora (dříve Rosenberg) nachází asi $3 \mathrm{~km}$ severním směrem od obce. V roce 1956 byly v trati Rosenberg zjištěny propadlé lochy (Unger 1987, 97). Jasnější odpověd' o přesné poloze vesnice přinesla až letecká prospekce z roku 1993 (Bálek 1997, 307). Na mírném návrší vzdáleném asi $1,2 \mathrm{~km}$ západně od Růžové hory odhalila 3-4 m širokou linii, interpretovanou jako prŕkop (obr. 3). Ten v porostu vymezoval obdélný půdorys uzavírající plochu o šířce ca $160 \mathrm{~m}$ se zřetelně se rýsující východní, severní a jižní stranou. Západní ukončení nebylo patrné (Bálek-Unger 1996, 431). Toto zjištění nám tedy dovoluje vymezit i předpokládaný rozsah vesnice. $\mathrm{K}$ tomu nám může dopomoci i v čase neměnný tvar již $\mathrm{v}$ úvodu zmíněného výběžku, který je definován hranicemi katastrálního území obce Dobré Pole. Výběžek je dobře patrný jak na císařských otiscích stabilního katastru z roku 1825, tak i na II. a III. vojenském mapování. Jeho šiřka je ca $160 \mathrm{~m}$ a je orientován ve směru východ-západ. Rozměrově a svým průběhem tak odpovídá prŕíkopu, který byl zjištěn leteckou prospekcí. Pro ověření zde byly J. Ungerem provedeny povrchové sběry, při kterých byla nalezena keramika především ze 14 ., eventuálně z počátku 15. století (Bálek-Unger 1996, 431).

Bohumělice (k. ú. Horní Věstonice, okr. Břeclav; obr. 5:10)

Zaniklá ves Bohumělice (v německé podobě Pochmalicz) se nachází v rovinatých polích v trati Na dlouhých (v nadmořské výšce ca $184 \mathrm{~m} \mathrm{n}$. m.) asi 2,2 km západně od středu obce Horní Věstonice. $\mathrm{V}$ písemných pramenech je zaniklá ves poprvé zmíněna $\mathrm{v}$ roce 1310 , kdy je na třech listinách týkajících se majetkových převodů zmíněn jako svědek jistý Haymel nebo Heinlín z Bohumilic (Pohemilicz, Pochmalicz). V první listině z 18. dubna 1310 přenechává Jindřich II. z Lichtenštejna se svou chotí Petruší a souhlasem syna Hartneida I. dolnokounickému klášteru nedalekou ves Dolní Dunajovice. Jedná se o latinský insert v listině z roku 1311 (Zemek-Turek 1983, 178 č. 48), který je insertem latinské listiny v listině z roku 1397 (Zemek-Turek 1983, 228 č. 220). Ve druhé a třetí listině z 13. července a 2. záŕí 1310, kde je opět jmenován jako svědek Haymel z Bohumilic, jde o odprodej tvrze v Nejdku Jindřichu II. z Lichtenštejna bratry Hadmarem a Rapatou z Falkenberka (Zemek-Turek 1983, 177 č. 145-146). Další zmínka o vsi pochází z roku 1332, kdy jsou Bohumělice součástí lichtenštejnského panství a společně s dalšími statky jsou vyňaty z placení zemské daně (CDM VI, 334-335 č. 438; Bistřický et al. 1991, 101 č. 60; Zemek-Turek 1983, 182 č. 64). Z písemných pramenů není jasné, jak se ves dostala z lichtenštejnských držav do rukou nižší šlechty, ale v roce 1377 svědčí jistý Jan, syn zesnulého Jana z Bohumilic, že odprodal bratřím z Lichtenštejna a na Mikulově všechen svůj svobodný statek, který vlastnil v Bohumilicích, a čtvrt mlýna (zamýšlen mlýn zvaný Velermühl) ležícího na řece Dyji u Mušova za 80 a půl hřiven vídeňských feniků (Bistřický et al. 1991, 203-204 č. 123; Zemek 1979, 143 č. 103; Zemek-Turek 1983, 203 č. 137). Další písemné zprávy pochází z roku 1380 a 1381 (Zemek-Turek 1983, 206 č. 147, 208 č. 150-152). V nich Jan I. z Lichtenštejna opakovaně doznává, že učinil nadaci na almužny a na záduší v kapli Panny Marie a sv. Jana Evangelisty na mikulovském 
hradě. Uvedené platy kromě jiného pochází z mlýna Velermühl v Bohumilicích. Takto je tomu i v př́ípadě zprávy z 11. listopadu 1380 (Bistřický et al. 1991, 229-233 č. 135; Zemek-Turek 1983, 207 č. 149), v níž dává mikulovské kapli roční důchod ve výši 19 liber a 21 feniků vlastního platu, z čehož 3 libry jdou z mlýna na věčné světlo v kapli a 16 liber a 21 feniků na záduší. Tento plat mělo odvádět vyjmenovaných 23 sedláků držících 18 a půl lánu a 9 podsedků ze vsi. Díky této zprávě tak víme nejenom o jménech jednotlivých poddaných $v$ Bohumilicích, ale i o rozsahu jejich pronajatého majetku (Bistřický et al. 1991, 231 č. 135). Poslední zmínka o vsi pochází i z lichtenštejnského urbáře z roku 1414. Zde je ovšem u vsi uvedeno jen prázdné místo, a lze tak předpokládat, že vesnice byla již v této době pustá (Bretholz 1930, 33; Nekuda 1961, 89). Jak ale uvádí J. Unger (Unger et al. 2017, 229), neznamená to, že vesnice byla pustá (Hosák 1967, 45; Nekuda 1961, 89), ale jen to, že platy z vesnice šly na zajištění mikulovské hradní kaple.

Na císařských povinných otiscích stabilního katastru Moravy a Slezska z roku 1825 je v místech vesnice jasně vyznačen ohraničený areál s názvem Oedesdorf - pustá ves. Areál je zřetelně vymezen od okolních polností a vnitřně členěn na devět víceméně plošně stejných parcel. Ohraničení areálu pak přesně koresponduje s porostovými př́iznaky zjištěnými za pomoci dálkového průzkumu Země. Ty jsou nejlépe patrné na ortofotosnímcích z let 2006 a 2009, kde je dobře viditelný tmavší lineární pás o šířce ca $5 \mathrm{~m}$, který ohraničuje areál vesnice ze všech světových stran. Na základě dostupných informací ho lze interpretovat jako zaniklý př́kop. Dle ortofotosnímku z roku 2009 se zdálo, že průběh příkopu byl na každé straně přerušen, a bylo tak možné uvažovat o jednotlivých vstupech do ohrazeného areálu. Jak ale ukázala plošná geofyzikální prospekce z nedávné doby (výsledky jsou stále předmětem zpracování), příkop je přerušen pouze na dvou stranách, a to na straně severní a jižní. Na těchto místech se tedy nacházely vstupy, popř́ípadě brány do ohrazeného areálu. Severní vstup je dobře viditelný i na leteckém snímku pořízeném M. Bálkem v roce 2001, na němž je spolu s ním dobře patrná i severní část ohrazení vesnice (obr. 7). Kromě př́íkopu byla vesnice ohrazena rovněž hliněným náspem. I přes dlouhodobou zemědělskou činnost jsou jeho zbytky dobře patrné na digitálním modelu reliéfu 5. generace získaném s pomocí leteckého laserového skenování, zejména pak na východní straně vesnice (obr. 9).

Západně od areálu se nachází další porostový příznak v podobě tmavé linie jdoucí ve směru sever-jih. Jak poukázali autoři v nedávno vydaném článku týkajícím se zaniklých Bohumělic (Unger et al. 2017), mělo by se jednat o pozůstatek historické cesty směřující od severního okraje Dolních Dunajovic k Novomlýnským nádržím. Tato dnes již zaniklá historická komunikace je dobře patrná i na císařských povinných otiscích stabilního katastru a mapě II. vojenského mapování. Výše zmíněný geofyzikální průzkum ale ukázal, že se jedná o př́íkop dosud neznámého ohrazeného areálu, který se nachází na západ od Bohumělic, v těsné blízkosti zaniklé vsi. Podle předběžné interpretace naměřených výsledků - půdorysného tvaru, velikosti areálu a vnitřního uspořádání sídlištních objektů - lze uvažovat o tom, že se s největší pravděpodobností jedná o starší fázi zaniklé vsi. Stárí lze nepř́ímo odvodit z toho, že vymezení původního východního ohrazeného areálu se dochovalo na historických mapách. Jistotu v chronologickém rozlišení obou areálů však může přinést až důkladný povrchový průzkum. Zmíněná zaniklá historická cesta pak vedla mezi př́kopy obou ohrazených areálů. Na ortofotosnímku z roku 2009 je dobře patrný její průběh v podobě světlejšího pásu. Ten se táhne od severu těsně vedle př́íkopu, při západní straně zaniklé vsi, na jihu prochází mezi dvěma př́kopy, z nichž ten západní patří nově objevenému ohrazenému areálu, a pokračuje směrem k jihu, kde se asi po 200 m stáčí mírně na jihozápad a pokračuje směrem na Dolní Dunajovice.

Geofyzikální průzkum s největší pravděpodobností vyvrátil i př́itomnost možného drobného opevněného sídla, které se mělo nacházet jižně od ohrazeného areálu. Zde je na ortofotosnímcích z roku 2009 dobře patrný koncentrický útvar porostových příznaků o průměru $40 \mathrm{~m}$ tvořený tmavším pásem o šířce přibližně $6 \mathrm{~m}$, v jehož středu se nachází plošný porostový příznak o rozměrech ca $17 \times 11 \mathrm{~m}$. Podle všeho se bud' jedná o čistě prŕírodní úkaz, nebo o prostý zásah do země, např́iklad z důvodu těžby zeminy apod. 


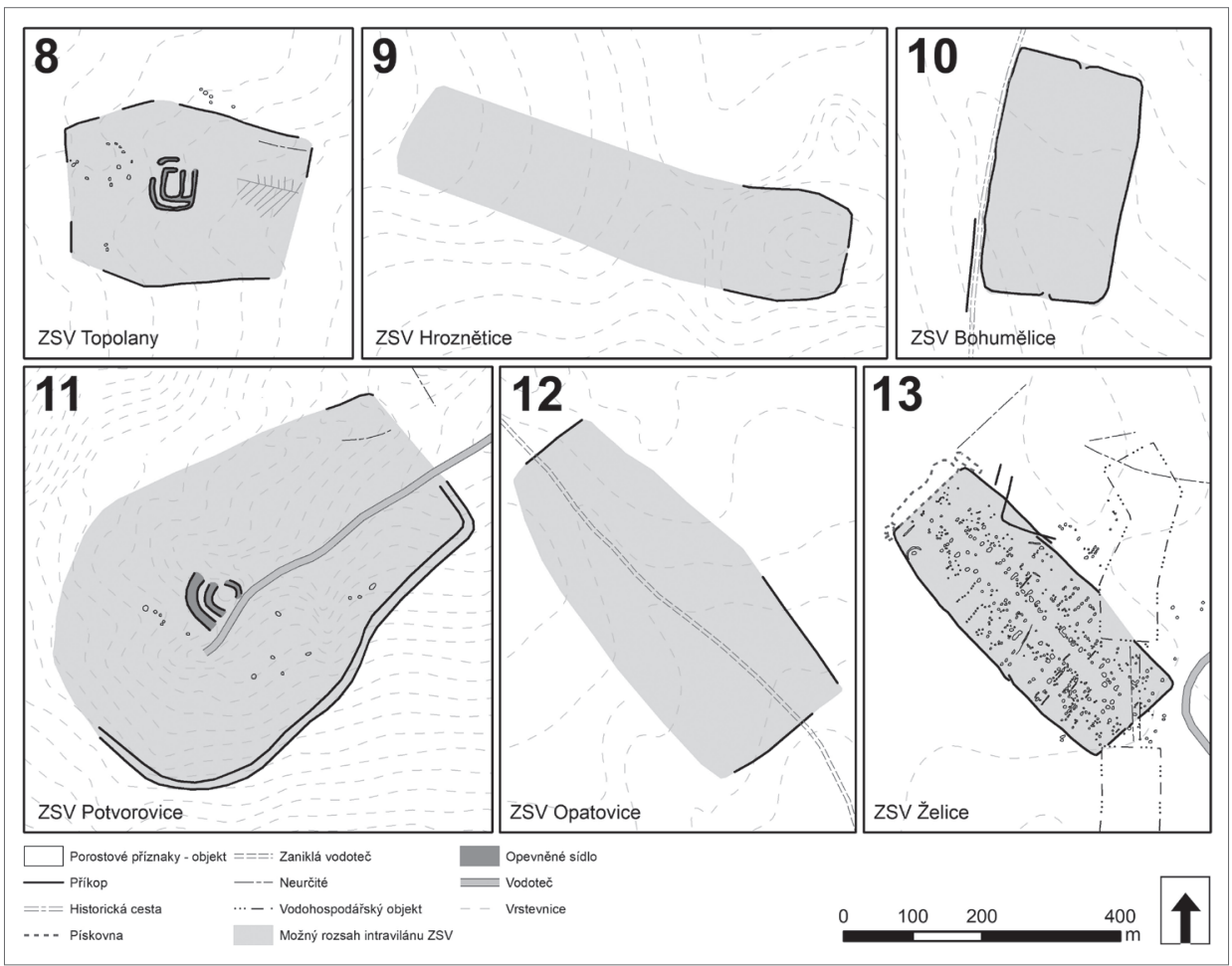

Obr. 5. Interpretace porostových příznaků na zaniklých středověkých ohrazených vesnicích.

Abb. 5. Interpretation der Vegetationsmerkmale an mittelalterlichen umfriedeten Dorfwüstungen.

Potvorovice (k. ú. Nový Poddvorov, okr. Hodonín; obr. 5:11)

Zaniklá středověká ves Potvorovice se nachází v trati Kosteliska, a to v těsné blízkosti obce Nový Poddvorov při jejím jihovýchodním okraji. První zmínku o vsi nalezneme v listině biskupa Roberta ze 7. května roku 1220, kde je ves zmiňována jako součást majetků velehradského kláštera (CDB II, 180 č. 195, 322 č. 321). V roce 1317 je ve vsi zmiňován klášterní dvůr se čtyřmi lány. $\mathrm{V}$ roce 1371 je opět zmiňován dvůr s přiléhajícími čtyřmi lány, dva od starodávna pusté lány a kostel. Vesnice je $\mathrm{v}$ této době propůjčována šlechticům na dobu jejich života (CDM X, 167 č. 140; CDM XI, 49-50 č. 58). Po vyplenění velehradského kláštera jsou Potvorovice v roce 1422 zastaveny správci kláštera Vojtěchovi. Po česko-uherských válkách jsou v roce 1482 už jako pusté zastaveny Protivcovi ze Zástřizl (Hurt 1934, 104, 125). Jako pusté se jmenují ještě několikrát, nejprve v roce 1539 (Hurt 1934, 162), posléze v roce 1540, kdy je v Potvorovicích mimo jiné zmiňováno pusté tvrziště a podací kostel (ZDB II, 284-285). Zmiňované tvrziště, které bylo při zápisu pouze mylně vizuálně charakterizováno, pak lze dát do souvislosti s bývalým opevněným dvorem. Další zmínky o zaniklé vsi pochází z let 1559 (ZDB II, 390-391) a 1622. V minulosti byly Potvorovice mylně označovány i jako městečko, což bylo v nedávné době odmítnuto L. Janem $(2010,81)$.

Podle písemných pramenů se tedy ve vsi nacházel jak kamenný kostel, tak i do klášterních majetků spadající opevněný hospodářský dvůr. Ten na sklonku své existence plnil podle všeho i funkci rezidenční. Celá ves pak byla obehnána náspem a př́íkopy. Ty jsou patrné jak na historických mapách, zejména pak na indikační skice a císařských povinných otiscích stabilního katastru 
z roku 1825 a na II. vojenském mapování z let 1836-1852, tak i na dnešních ortofotosnímcích. Jedná se zejména o snímky z let 2006, 2009, 2012 a 2015. Ohrazení vesnice zachytil leteckým snímkováním i M. Bálek v roce 1998 (obr. 7). Díky porostovým prŕznakům jsou dobře viditelné zbytky zdvojeného př́ikopu v podobě tmavých pásů táhnoucích se okolo zaniklé vsi. Tyto tmavší linie o šířce ca $5 \mathrm{~m}$ jsou dobře zřetelné zejména na jihozápadní a jihovýchodní straně zaniklé vsi, kde je dobře patrné i nároží stáčející se směrem na severozápad, kde linie kopírují průběh polní cesty. Severní strana zaniklých Potvorovic se bohužel ztrácí pod dnešní zástavbou v podobě zahrádek. V kombinaci s informacemi získanými z historických map je tak možné říci, že zaniklá ves Potvorovice měla protáhlý hruškovitý tvar, který se směrem k severovýchodu zužoval. Celkový plošný rozsah ohrazeného areálu se pohyboval okolo 21 ha. Délku samotného náspu s př́íkopy lze odhadnout na ca $1,75 \mathrm{~km}$. Na ortofotosnímcích jsou patrné i další porostové příznaky ve formě tmavších ploch, které lze interpretovat jako relikty sídlištních objektů, poprrípadě jako zbytky po jednotlivých usedlostech. Tyto stopy po vesnické zástavbě jsou dobře viditelné zejména na nejnovějších ortofotosnímcích z let 2006, 2009 a 2015, a to v jižní a jihovýchodní části ohrazeného areálu. Př́ítomnost sídlištních objektů byla archeologicky potvrzena v roce 1997, kdy byly na lokalitě prozkoumány dva propadlé lochy (NZ č. j. 253/98, ulož. v archivu ARÚ Brno).

Na snímcích z let 2006 a 2009 je dobře patrný i další výrazný porostový příznak. Zhruba uprostřed zaniklé vsi, v blízkosti menší vodoteče, která vyvěrá ve středu vesnice, jsou na ortofotosnímcích viditelné dva do kruhu se stáčející tmavší pásy. Jedná se o zbytky opevnění, pravděpodobně v podobě dvou př́ikopů, které obtáčely vyvýšenou plošinu o rozměrech ca $22 \times 35 \mathrm{~m}$. Na ní se pravděpodobně nacházel již výše zmíněný dvůr. Společně s náspem, který se vinul okolo vesnice, byl tento terénní relikt v krajině dobře patrný až do poloviny 70 . let minulého století (obr. 6; Klanica 1973; Měřínský 1977), kdy byla v zimě 1974/1975, bez vědomí archeologů, část pahorku a okolního náspu srovnána se zemí těžkou technikou. Zároveň byly podle dostupných informací srovnány s okolním terénem i zbytky hliněných náspů obklopujících zaniklou ves.

Podle písemných pramenů stál ve vesnici kamenný kostel, jehož základy byly ještě v 18. století v terénu dobře patrné. Podle pamětníků z Nového Poddvorova ho lze lokalizovat někam do severní části zaniklé vesnice, tedy do míst dnešních zahrádek (vyslechnuto jedním z autorů článku). Kolem kostela se musel nacházet hřbitov. Při hloubení plynovodu v roce 1972 bylo v trati Podkovné, asi 800 m východně od středu nynější obce, zachyceno 13 kostrových hrobů, které bylo možno datovat na základě nálezů mincí a esovitých záušnic do druhé poloviny 11. století (Klanica 1973). Podle Z. Klanici mohl hřbitov patřit k zaniklému Poddvorovu, což by rámcově odpovídalo i první zmínce o vsi z roku 1220. Pokud však přijmeme myšlenku, že zaniklý kostel

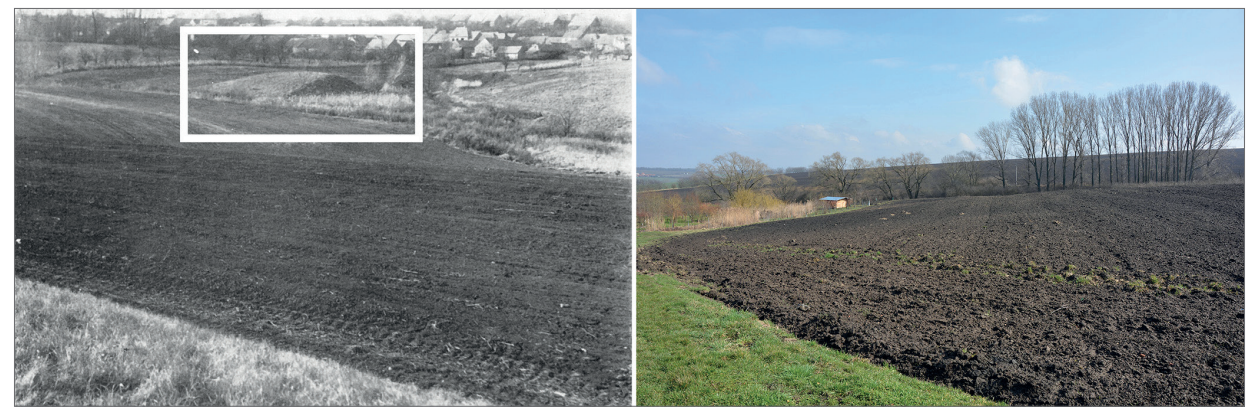

Obr. 6. Pohled na ZSV Potvorovice. Vlevo pohled od východu z trati Podkovná z roku 1972 - v bílém rámečku je dobře patrný pahorek tzv. „tvrziště“, jehož zbytky byly srovnány s okolním terénem v roce 1975. Foto podle Klanica 1973, tab. 46, 154. Vpravo pohled od kraje Nového Poddvorova ze severozápadu, dnešní stav. Foto M. Vágner.

Abb. 6. Blick auf die mittelalterliche Dorfwüstung Potvorovice. Links Blick aus Osten von der Lage Podkovná aus dem Jahr 1972 - im weißen Rahmen ist der Hügel der sog. „Festungsstätte“ gut sichtbar, dessen Überreste 1975 mit dem umliegenden Gelände verglichen wurden. Foto nach Klanica 1973, Taf. 46, 154. Rechts Blick vom Rand von Nový Poddvorov von Nordwesten, heutiger Zustand. Foto M. Vágner. 

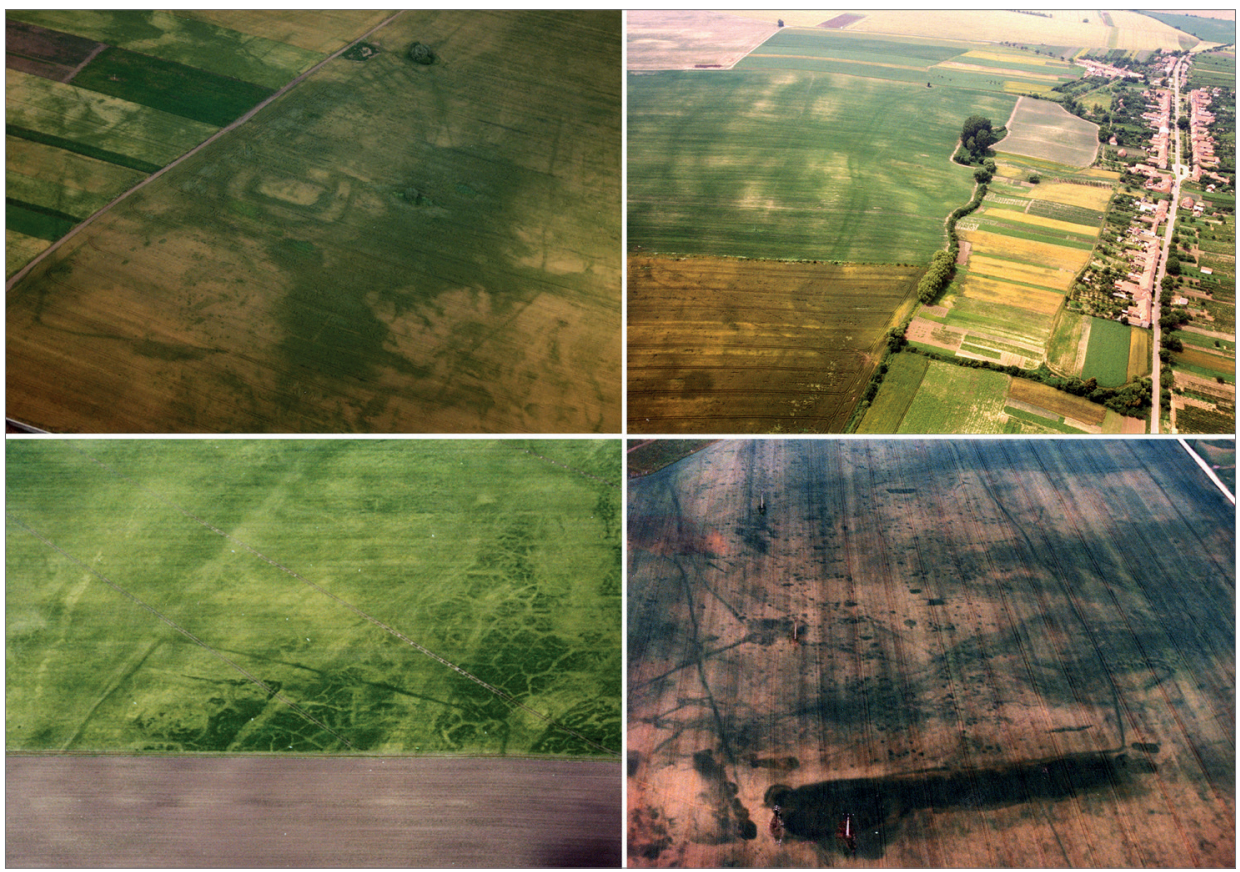

Obr. 7. Letecké snímky pořízené Miroslavem Bálkem. Nahoře vlevo: Pohled na ZSV Topolany (k. ú. Vranovice; okr. Brno-venkov) od jihozápadu; nahoře vpravo: ZSV Potvorovice (k. ú. Nový Poddvorov; okr. Hodonín) od severovýchodu; dole vlevo: ZSV Bohumělice (k. ú. Horní Věstonice; okr. Břeclav) od jihu; dole vpravo: ZSV Želice (k. ú. Přísnotice; okr. Brno-venkov) od severozápadu. Zdroj archiv ÚAPP Brno.

Abb. 7. Von Miroslav Bálek gemachte Luftbildaufnahmen. Oben links: Blick auf die mittelalterliche Dorfwüstung Topolany (Katastergebiet Vranovice; Bezirk Brno-Land) von Südwest; oben links: mittelalterliche Dorfwüstung Potvorovice (Katastergebiet Nový Poddvorov; Bezirk Hodonín) von Nordost; unten links: mittelalterliche Dorfwüstung Bohumělice (Katastergebiet Horní Věstonice; Bezirk Břeclav) von Süden; unten rechts: mittelalterliche Dorfwüstung Želice (Katastergebiet Př́ísnotice; Bezirk Brno-Land) von Nordwest. Quelle Archiv des Instituts für archäologische Denkmalpflege Brno.

se nacházel někde v místech dnešních zahrádek, tedy asi 400 m severním směrem od místa nálezu hrobů, zachycené pohřebiště patrně fungovalo ještě před založením samotného kostela. I když byl kostel založen pravděpodobně mnohem dříve, první zmínka o něm pochází až z roku 1371, tedy o ca 300 let později.

Opatovice (k. ú. Hrušky, okr. Břeclav; obr. 5:12)

Zaniklá středověká ves Opatovice se nachází v severovýchodní části katastru obce Hrušky v trati Opatovské, a to necelé $2 \mathrm{~km}$ severně od středu obce. První zmínka pochází z roku 1141, kdy celá ves náležela k břeclavskému hradskému kostelu (CDB I, 122 č. 115; Hosák 1967, 51; Žemlička 1997, 246-248). Na počátku 14. století byla ves biskupským lénem a měla 28 lánů a 9 podsedků. Jako osedlá je připomínána ještě k roku 1437, kdy ji držel Artléb ze Zástřizl (do léna byl uveden v roce 1435; Lechner 1902, 105). V roce 1512 ji už jako pustou vložil Proček ze Zástřizl a na Ždánicích Heraltovi Kunovi z Kunštátu. Jako pustá je ještě zapisována v roce 1542 (Nekuda 1961, 67).

Lokalita se nachází v mírném údolí v nadmořské výšce ca $180 \mathrm{~m}$ n. m., na dlouhodobě obdělávaném poli, jehož středem se táhne drenážovaná vodoteč. Orientována je ve směru od severozápadu k jihovýchodu, kde se nevýrazné údolí pozvolna rozšiřuje. Na severozápadní straně je dnes ohraničena polní komunikací, na jihozápadní straně zatravněnou a křovím porostlou mezí. Toto vymezení je společně s bývalou vodotečí dobře patrné i na povinných císařských 
otiscích stabilního katastru pro obec Hrušky z roku 1827, kde je lokalita na jihozápadní straně ohraničena dnes již zaniklou polní cestou. Stejná situace se opakuje i na II. vojenském mapování z roku 1841, kde ovšem není ve středu vesnice zaznamenána vodoteč. Na III. vojenském mapování z roku 1882 je prostor vesnice na jihozápadě opět vymezen polní cestou. Ostatní strany jsou však podle této mapy ohraničeny př́ḱkopem. Ve středu vesnice je opět zaznamenáno koryto vodoteče. Ze studia mapových podkladů tedy vyplývá, že vesnice byla vymezena př́ikopem, který byl až do poslední čtvrtiny 19. století zatravněn a využíván k sečení nebo pastvě. Středem vesnice protékala vodoteč v korytě, které bylo ve 20 . století svedeno do trubek. K jeho zanesení došlo zřejmě až na začátku 20. století, případně na počátku 20. let 20. století ve spojení s pozemkovými úpravami po vzniku ČSR (Dresler-Tencer-Vágner 2015a, 116).

Oba tyto prvky jsou pak dodnes dobře viditelné i na ortofotosnímcích. Zbytky př́kopu jsou patrné na severozápadní, severovýchodní a jihovýchodní straně zaniklé vesnice. V severozápadní části byl tento př́íkop potvrzen i geofyzikální prospekcí. S pomocí magnetometru se zde podařilo zachytit nejen jeho severní nároží, ale byla identifikována i další lineární struktura, která byla interpretována jako pozůstatek žlabu. Ten se nachází asi $15 \mathrm{~m}$ od zachyceného příkopu a kopíruje jeho průběh. Podle rozměrů lze usuzovat, že se pravděpodobně jedná o druhý př́kop a vesnice byla v těchto místech ohrazena dvojitě. V severozápadní části plochy byly geofyzikální prospekcí nově zjištěny i pozůstatky kamenné stavby, která byla interpretována jako jednolodní kostel. Tato domněnka byla potvrzena vrtnou sondáží a povrchovými sběry (Dresler-Tencer-Vágner 2015a).

Díky leteckým snímkům se ca 300 m jihovýchodně od lokality podařilo identifikovat další lineární strukturu, která se táhne směrem z jihozápadu na severozápad. Pravděpodobně se však jedná o recentní inženýrskou sít'.

Želice (k. ú. Přísnotice, okr. Brno-venkov; obr. 5:13)

ZSV Želice se nachází v trati Želiska asi 2,6 km jihovýchodně od středu obce Přísnotice. Lokalita se nachází na poli v rovinatém terénu v těsné blízkosti říčky Šatava asi $175 \mathrm{~m} \mathrm{n}$. m. V písemných pramenech je ves poprvé zmiňována v roce 1360, kdy zde zapisuje Pěšík z Želic dvůr, dva podsedky a les (ZDB, 43 č. 579). O dva roky později je v Želicích zmiňován dvůr se čtyřmi lány a šesti podsedky (ZDB, 49 č. 85). Nižší šlechta přichází o svůj díl Želic (nazývaných Želízko), tehdy již pustých, v roce 1491, kdy je kupuje Vilém z Pernštejna od Havla z Batelova (AČ XVI, 285-288 č. 325, 328). Druhou část vesnice nejpozději od konce 14. století vlastnila brněnská kapitula, ještě v roce 1481 je uváděno 12 gruntů, jako pustá se uvádí v roce 1535 (Hosák 1967, 43; blíže k historii vesnice Mlateček 2012; Nekuda 1961, 76-77).

V roce 1992 byl nad lokalitou proveden M. Bálkem letecký průzkum (obr. 7), který odhalil 1,2 km dlouhou a 2,5 m širokou linii vymezující obdélný areál o ploše 7,5 ha (Bálek-Unger 1996, 434-437). Linie byla interpretována jako zbytky př́kopu. Podle leteckých snímků se zdá, že prríkop byl přerušen minimálně na jihovýchodní straně, kde je areál vesnice částečně narušen i vodárenským objektem. Na severozápadní straně můžeme průběh př́íkopu pouze tušit, protože je v těchto místech narušen bývalou pískovnou. Podle leteckých snímků není ale vyloučeno, že prríkop byl přerušen i na delších stranách ohrazeného areálu, tedy na jeho jihozápadní a severozápadní straně. Na severozápadní straně je průběh příkopu narušen dalšími lineárními útvary, které lze interpretovat jako další zbytky příkopů či žlabů. Pravděpodobně se jedná o část ohrazení bud' staršího, nebo mladšího areálu s podobnou funkcí. Směrem na severozápad od vesnice byl patrný další tmavý pás, který byl interpretován jako recentní zásah. Jak na leteckých snímcích z roku 1992, tak i na novějším ortofotosnímku z roku 2016 jsou uvnitř ohrazeného areálu vesnice patrné porostové příznaky v podobě větších a menších tmavších plošných, bodových a liniových útvarů, které lze interpretovat jako pozůstatky různých sídlištních objektů, kůlových jam, sklepů, zásobních jam, žlabů, popř́ípadě pyrotechnických zařízení apod. Uspořádány jsou kolmo na delší osu ohrazeného areálu, a to po obou stranách 20-25 m širokého středového pásu bez porostových příznaků. Na základě koncentrace, orientace a prostorového rozložení identifikovaných 
objektů lze rekonstruovat půdorysnou podobu zaniklé vsi. Ta byla tvořena asi 25 usedlostmi, pravděpodobně dřevěné, respektive dřevohlinité konstrukce, které byly štítem situovány do uliční návsi (Bálek-Unger 1996, 436). Výsledky leteckého průzkumu byly v nedávné době potvrzeny plošným geofyzikálním průzkumem, jehož výsledky budou publikovány v nejbližší době.

\section{Diskuse a závěr}

Studium volně dostupných digitálních ortofotosnímků a historických mapových archiválií přineslo nové poznatky ve výzkumu vrcholně a pozdně středověkých ohrazených vesnických sídel. Vnější ohrazení ve formě jednoduchého, někdy i vícenásobného příkopu bylo opětovně potvrzeno na několika již známých lokalitách, o kterých se vědělo bud' z leteckých prospekcí M. Bálka uskutečněných počátkem 90 . let minulého století nebo z terénních prospekcí prováděných na konci let sedmdesátých. Z lokalit identifikovaných $\mathrm{v}$ rámci letecké prospekce se jedná o zaniklý Koválov (k. ú. Žabčice; obr. 3; obr. 4:4), Hroznětice (k. ú. Dobré Pole; obr. 3; obr. 5:9), Topolany (k. ú. Vranovice; obr. 5:8; obr. 7), Želice (k. ú. Př́ísnotice; obr. 5:13; obr. 7), z terénního průzkumu o zaniklé Potvorovice (k. ú. Nový Poddvorov; obr. 5:11). Nově se vnější ohrazení podařilo identifikovat u zaniklého Prechova (k. ú. Moravský Žižkov; obr. 4:1), Vsiska (k. ú. Dolní Bojanovice; obr. 4:6), „Starého“"Mistřína (k. ú. Mistřín; obr. 4:5), Kapanska (k. ú. Mutěnice; obr. 4:7), Bohumělic (k. ú. Horní Věstonice; obr. 5:10) a Opatovic (k. ú. Hrušky; obr. 5:12). Je možné, že nějakou formou vnějšího ohrazení disponovaly i zaniklé Divice (k. ú. Brumovice; obr. 4:5) a Jarohněvice (k. ú. Dubňany; obr. 4:3). Lineární porostové příznaky, které by bylo možné interpretovat jako zbytky př́kopů, zachytil v místech zaniklých vesnic již M. Bálek (obr. 3). Pokud by se podařilo tyto interpretace potvrdit, počet ohrazených vesnic a městeček v širší oblasti Dolnomoravského a Dyjsko-svrateckého úvalu by tak stoupl z dosavadních jednadvaceti na devětadvacet lokalit (obr. 8).

Kromě jednoduchých nebo dvojitých př́íkopů byly vesnice obehnány i sypanými hliněnými valy. Jednak bylo potřeba někam umístit vytěženou hlínu, jednak byly dalším funkčním prvkem v ohrazení vesnice. V krajině jižní Moravy je dnes jejich identifikace kvůli odlesnění a následné intenzivní zemědělské činnosti bohužel komplikovaná, není však nemožná. O jejich existenci nepřímo vypovídají některé tratové názvy v místech zaniklých vesnic. Tak je tomu např́iklad u ZSV Kapansko, v jejichž místech se dodnes nachází trat' Na valech. K některým lokalitám se pak vážou vzpomínky pamětníků. To se týká např́íklad zaniklých Potvorovic. Podle vyprávění pamětníků zde byly patrné zbytky „,valư“ před jejich rozoráním ještě do poloviny 70 . let 20 . století. Dále je možné, že u některých zaniklých vesnic jsou pozůstatky náspů zaneseny i v některých historických mapových archiváliích. Zde ale může nastat problém s čitelností těchto map, respektive s interpretací jednotlivých prvků na mapě. To, co je na historické mapě zaneseno jako linie nebo soubor linií, které svým průběhem obtáčí zaniklou ves a které nyní interpretujeme jako př́íkop, může být tehdejším tvůrcem zamýšleno i jako vyobrazení náspu, popř́ípadě obou terénních prvků. Důkaz, že vesnice byly v minulosti ohrazeny jak prŕikopem, tak i náspem pak přináší další z metod dálkového průzkumu Země - letecké laserové skenování. Jako příklad lze uvést výše popsanou ZSV Bohumělice. U této lokality jsou na digitálním modelu terénu 4., ale zejména 5. generace dobře patrné zbytky náspů, které zaniklou ves obepínaly ze všech čtyř světových stran. Dalším př́íkladem z území Moravy, i když z jiné části, jsou již v úvodu zmíněné Dašovice. V místech vsi jsou dodnes velice dobře patrné jak terénní relikty po jednotlivých usedlostech a pozůstatky menšího opevněného feudálního sídla kruhové dispozice, tak i pozůstatky př́íkopů s náspy po jejich obvodu. Ty zaniklou ves ohrazovaly nejméně ze tří stran. Bohužel, nedávné zásahy do krajiny, zejména zemědělství s použitím těžké techniky a scelování polností, přispěly k tomu, že tyto terénní relikty jsou v dnešní krajině nadobro ztraceny a nelze je identifikovat ani na detailnějším digitálním modelu reliéfu. Daleko lépe jsou na tom v sousedním Dolním Rakousku. Jak už bylo řečeno v úvodu, v nedávné době se podařilo v širším okolí obce Enzersdorf s pomocí leteckého laserového skenování zdokumentovat několik zaniklých středověkých vesnic. Některé z lokalit pak byly objeveny zcela nově. Díky tomu, že se zachycené vesnice nacházely 


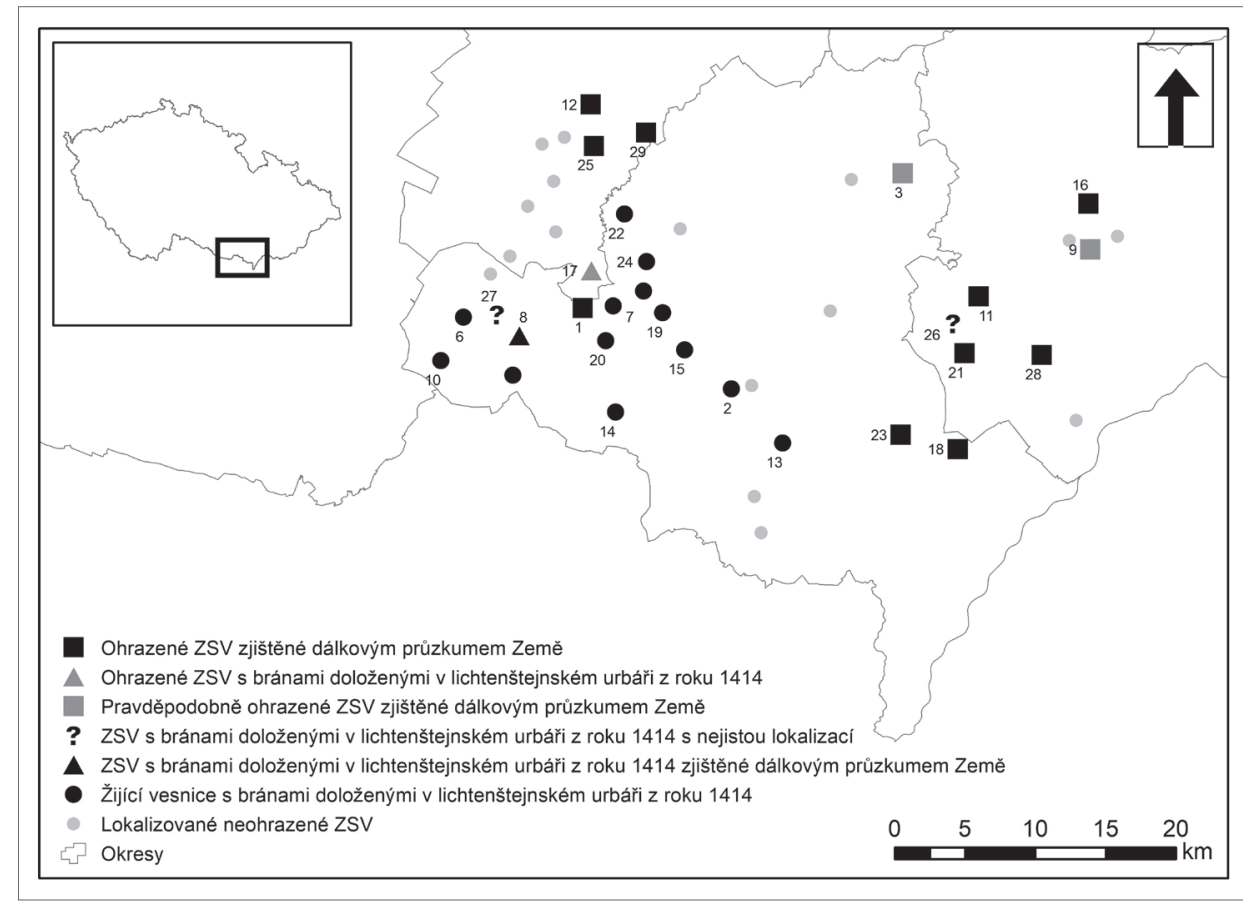

Obr. 8. Ohrazené vesnice na sledovaném území. 1 - Bohumělice; 2 - Bulhary; 3 - Divice; 4 - Dobré Pole; 5 - Dolní Věstonice; 6 - Drnholec; 7 - Horní Věstonice; 8 - Hroznětice; 9 - Jarohněvice; 10 - Jevišovka; 11 - Kapansko; 12 - Koválov; 13 - Lednice; 14 - Mikulov; 15 - Milotice; 16 - Mistřín; 17 - Mušov; 18 - Opatovice; 19 - Pavlov; 20 - Perná; 21 - Potvorovice; 22 Pouzdřany; 23 - Prechov; 24 - Strachotín; 25 - Topolany; 26 - Ulvy; 27 - Ves Nová; 28 - Vsisko; 29 - Želice.

Abb. 8. Umfriedete Dörfer im beobachteten Gebiet. 1 - Bohumělice; 2 - Bulhary; 3 - Divice; 4 - Dobré Pole; 5 - Dolní Věstonice; 6 - Drnholec; 7 - Horní Věstonice; 8 - Hroznětice; 9 - Jarohněvice; 10 - Jevišovka; 11 - Kapansko; 12 - Koválov; 13 - Lednice; 14 - Mikulov; 15 - Milotice; 16 - Mistř́n; 17 - Mušov; 18 - Opatovice; 19 - Pavlov; 20 - Perná; 21 - Potvorovice; 22 - Pouzdřany; 23 - Prechov; 24 - Strachotín; 25 - Topolany; 26 - Ulvy; 27 - Ves Nová; 28 - Vsisko; 29 - Želice.

v lesním prostředí, a nebyly tedy nijak výrazně dotčeny zemědělskou ani jinou činností, jsou jejich zbytky v terénu velice dobře patrné, a to včetně pozůstatků po ohrazení - několik metrů širokých př́kopů a hliněných náspů.

Z archeologických výzkumů, ikonografických pramenů a etnologických analogií víme, že jednotlivé usedlosti, popř́ípadě celé parcely, mohly být od sebe navzájem odděleny různými formami ohrazení. Podobně jako tomu bylo u konstrukce obytných a hospodářských budov, jeho podoba závisela na dostupnosti konkrétního stavebního materiálu v dané oblasti, stejně jako na regionální stavební tradici. Mohlo se jednat o kamenné zídky, dřevěné palisády a ploty či o prosté pásy křoví. Ty nejenže měly za úkol členit samotný intravilán vesnice, ale mohly hrát i doplňující roli ve vnějším ohrazení celého areálu. Pokud tomu tak bylo, tak z funkčního hlediska je nejlogičtější, že se tyto zátarasy nacházely na vrcholku hliněného náspu. Co se týče konstrukce, v případě jižní Moravy se jeví jako nejpravděpodobnější, že měly podobu dřevěného plotu či se jednalo o pouhý pás náletového křoví.

Pokud jde o účel samotného ohrazení, nabízí se několik možností. Primární funkcí, pro kterou se již v minulosti vyslovil i J. Unger, byla funkce právní (Bálek-Unger 1996, 439). Při aktu založení vesnice byl jasně vymezen rozsah, popřípadě velikost jednotlivých parcel dané vesnice. Vnější ohrazení pak definovalo majetkový a právní rozsah dané osady a umožňovalo tak rozdílné posouzení skutků uvnitř a vně ohrazeného areálu. Dále si lze představit, že takto ohrazený areál $\mathrm{s}$ předem danými vstupy, které mohly být navíc $\mathrm{v}$ prrípadě potřeby uzavírány branami, měl funkci 


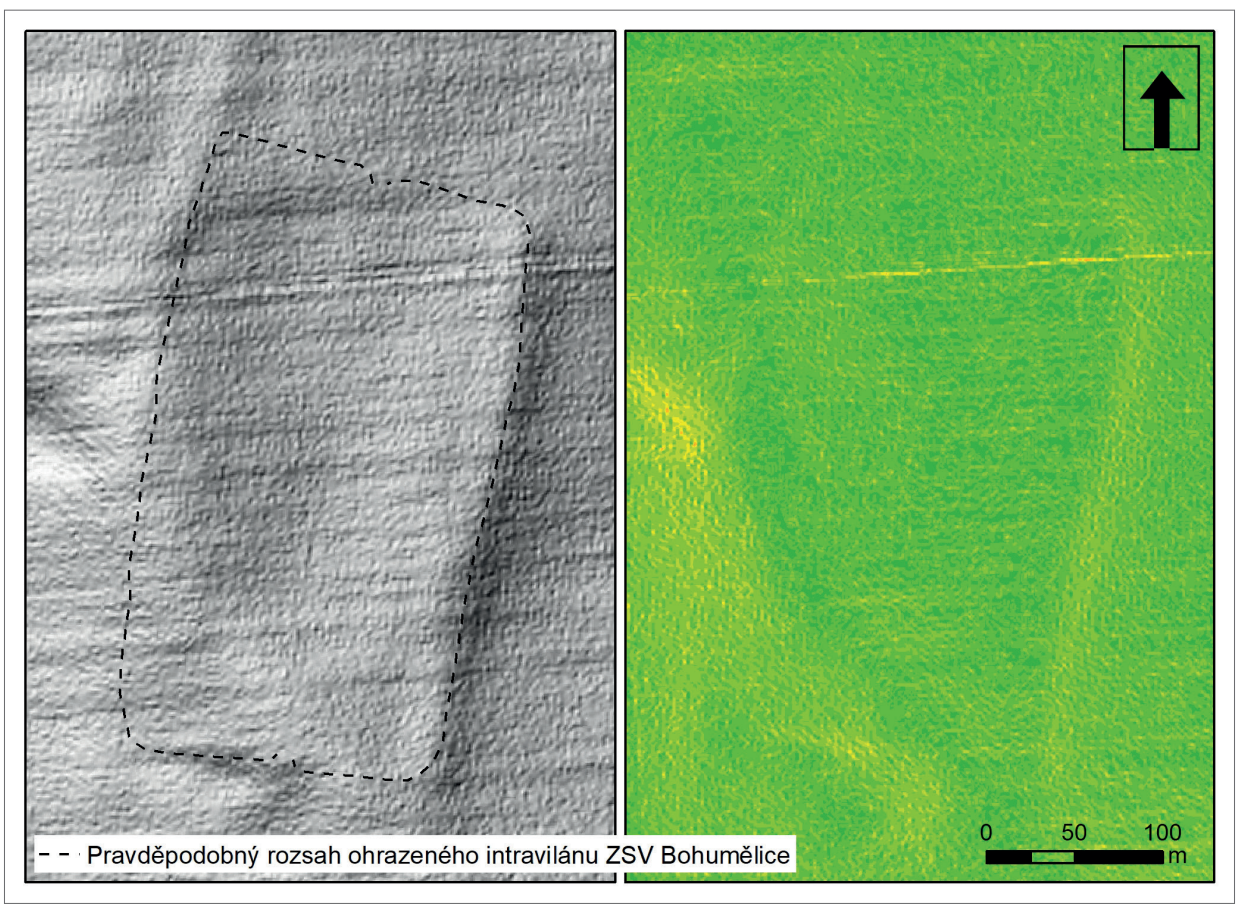

Obr. 9. Digitální model reliéfu 5. generace ZSV Bohumělice získaný za pomoci leteckého laserového skenování. Vlevo stínovaný model reliéfu (10krát převýšený); vpravo Aspect Range (orientace svahů). Zdroj ČÚZK.

Abb. 9. Durch Airborne Laserscanning gewonnenes digitales Reliefmodell der 5. Generation von der mittelalterlichen Dorfwüstung Bohumělice. Links Schattenmodell des Reliefs (zehnfach vergrößert); rechts Aspect Range (Orientierung der Hänge). Quelle Tschechisches Amt für Landesvermessung und Kataster.

ochrannou, popřípadě obrannou. V př́ípadě pasivní ochranné funkce, tedy bez zapojení člověka, mohlo ohrazení bránit v pohybu zviŕrat. Divoká zvěř se nedostala dovnitř ohrazeného areálu a naopak, již zdomácnělá zvířata se nedostala mimoděk ven. Co se týče aktivní obranné funkce, tu prozatím nelze potvrdit a ani vyloučit. Příkop s náspem, který by navíc na svém vrcholu měl i nějakou lehčí formou zátarasu a byl by z druhé strany aktivně bráněn, by menší neorganizovanou skupinu útočníků pravděpodobně odradil. Otázkou zůstává, zda by ty to fortifikační prvky obstály při nějakém větším, lépe organizovaném útoku. Podle toho, kolik vesnic, ohrazené nevyjímaje, bylo zdevastováno během nejrůznějších válečných událostí, si lze domyslet, že pravděpodobně nikoliv. V souvislosti s objevem zaniklých vesnic v okolí Enzersdorfu se proti myšlence obranné funkce ohrazení vyslovil i rakouský historik Heinz Bidner. Ten se domnívá, že zdejší identifikované př́íkopy o průměrné šířce čtyři až šest metrů a hloubce pouhé dva metry by tuto funkci plnit nemohly. V mnoha př́ípadech byl kromě vnitřního většího valu zachycen i násep menší, který se táhl po vnější straně př́íkopu. Podle něj by v př́ípadě napadení vesnice poskytoval tento prvek útočníkům ochranu v podobě potenciálního krytu. Společně s archeologem Gerhardem Hasenhündlem se domnívá, že tyto př́ikopy primárně sloužily jako odvodňovací kanály při velkých deštích, popř́ípadě jako ochrana před záplavami. ${ }^{1}$ Nesmíme zapomenout i na další, poněkud opomíjený, ale ve smýšlení tehdejšího člověka jistě důležitý aspekt - psychologický. V Legendě o Ostojovi (Smetánka 2004, 46-47) Z. Smetánka v souvislosti s ohrazením prosté usedlosti uvádí, že: „(...) odděluje bezprostředně osvojený prostor, v jistém smyslu tedy bezpečný prostor

1 Zmíněno na https://www.enzersdorf-im-thale.at/versunkene-orte/. 
,zde u nás', od nejistého prostoru ,tam za', tedy od prostoru neosvojeného nebo jen podmíněně osvojeného, jako jsou pro Ostoje pole, a tudiž prostoru, kde zvláštěs nastávajicím večerem hrozi nebezpeči skutečná i nebezpeči smyšlená, zrozená fantazií z nedostatečně poznaného světa. "Toto tvrzení se zde sice vztahuje jen na Ostojovu usedlost, ale lze ho aplikovat ve vztahu k okolní krajině i na daleko větší prostor - např́iklad na celou vesnici.

I přes detailní analýzu všech dostupných zdrojů z dálkového průzkumu Země může být ohrazení u dvou zaniklých vesnic - Divic (k. ú. Brumovice) a Jarohněvic (k. ú. Dubňany) - stále otázkou diskuse a bylo by jej potřeba ověřit terénním průzkumem. V tom se nejlépe osvědčila geofyzikální prospekce. V nedávné době se na několika vybraných lokalitách podařilo metodou magnetometrie identifikovat jak vnější ohrazení v podobě př́ikopů, tak i vnitřní půdorysné uspořádání zaniklých vsí. Prozatím se podařilo kompletně prozkoumat zaniklou ves Opatovice, kde byl mimo jiné identifikován i menší jednolodní kamenný kostel (Dresler-Tencer-Vágner 2015; 2015a), Vsisko u Dolních Bojanovic (Vágner et al. 2018), Želice u Přísnotic a Bohumělice u Horních Věstonic. U posledních dvou jmenovaných vesnic odhalil geofyzikální průzkum druhý, ohrazením a půdorysnou dispozicí podobný areál, který s ní byl bud' v superpozici (v případě Želic) nebo se nacházel v těsné blízkosti zaniklé vsi (v případě Bohumělic). Částečně pak byla provedena geofyzikální prospekce na ZSV „Starý“ Mistřín (k. ú. Mistřín), kde se podařilo prozkoumat polovinu zaniklé vsi. Dále byl proveden menší ověřovací geofyzikální průzkum v místech jihozápadního rohu ZSV Prechov, kde se podařilo potvrdit ohrazení v podobě př́kopu.

Práce byla podpořena projektem MUNI/A/0839/2019 „Archeologické terénní prospekce, exkavace, dokumentace a muzejní prezentace IX“.

\section{Prameny}

AČ: Archiv český čili staré písemné památky české i moravské XVI (Dvorský, F., ed.). Praha 1897.

CDB: Codex diplomaticus et epistolaris regni Bohemiae I-VI, 805-1283 (Friedrich G.-Kristen, Z.-Šebánek, J.-Dušková, S.-Sviták, Z.-Krmíčková, H.-Krejčíková, J.-Nechutová J., edd.). Praha 1904-2006.

CDM: Codex diplomaticus et epistolaris Moraviae VI-XII, 1307-1399 (Chytil, J.-Brandl, V., edd.). Brno $1854-1890$.

LCS: Libri citationum et sententiarum seu Knihy půhonné a nálezové IV-VII, 1459-1503 (Brandl, V.Bretholz, B.). Brno 1881-1911.

MSL: Moravské a slezské listiny liechtenštejnského archívu ve Vaduzu I, 1173-1380 (Bistřický, J.Spurný, F.-Václavek, L.-Zemek, M., edd.). Brno 1991.

MV: Monumenta Vaticana res gestas Bohemicas illustrantia III, 1362-1370 (Jenšovský, B., ed.). Praha 1944. PB: Knihy půhonné práva brněnského, Zemský archiv v Brně.

PH 1691: Moravský zemský archiv, fond G 10 Sbírka rukopisů archivu, inv. č. 592, Panství hodonínské 1691. ZDB: Moravské zemské desky (Die Landtafel des Markgrafthumes Mähren). I. sv. řady brněnské 13481466 (Chlumecký, P.-Chytil, J.-Demuth, K.-Wolfskron, A., edd.). Brno 1856.

ZDB II: Moravské zemské desky. Kraj brněnský II. 1480-1566 (Kalina, T., ed.). Praha 1950.

ZDO: Moravské zemské desky (Die Landtafel des Markgrafthumes Mähren). I. sv. řady olomoucké 13481466 (Chlumecký, P.-Chytil, J.-Demuth, K.-Wolfskron, A., edd.). Brno 1856.

\section{Literatura}

BÁLEK, M., 1997: Výsledky leteckého snímkování na Moravě, PV 38, 307-311.

BÁLEK, M.-KNECHTOVÁ, A., 1999: Aplikace leteckého snímkování při tvorbě SAS ČR na Moravě v roce 1997, PV 40, 391-393. 
BÁLEK, M.-UNGER, J., 1996: Ohrazené stř̌edověké vesnice na jižní Moravě - Umfriedigte mittelalterliche Dörfer in Südmähren, AH 21, 429-442.

- 1996a: Umgrenzte mittelalterliche Dörfer in Südmähren. In: Ruralia I. Památky archeologické - Supplementum 5, 296-300. Praha.

BIERMANN, F., 2003: Handwerk und Handel im Dorf der Ostsiedlungszeit, Beispiele aus brandenburgischen Wüstungen, Ethnographisch-Archäologische Zeitschrift 44, 539-573.

- 2010: Archäologische Studien zum Dorf der Ostsiedlungszeit. Die Wüstungen Miltendorf und Damsdorf in Brandenburg und das ländliche Siedlungswesen des 12. bis 15. Jahrhunderts in Ostmitteleuropa. Forschungen zur Archäologie im Land Brandenburg 12. Wünsdorf.

BIERMANN, F.-MANGELSDORF, G., edd., 2005: Die bäuerliche Ostsiedlung des Mittelalters in Nordostdeutschland: Untersuchungen zum Landesausbau des 12. bis 14. Jahrhunderts im ländlichen Raum. Beiträge einer interdisziplinären Tagung des Lehrstuhls für Ur- und Frühgeschichte der Universität Greifswald, 16. und 17. April 2004. Vol. 7. Frankfurt.

BISTŘICKÝ, J., 1998: Zdíkovy listiny, ČČH 96, 292-306.

BISTŘICKÝ, J. et al., 1991: Bistřický, J.-Spurný, F.-Václavek, L.-Zemek, M., Moravské a slezské listiny liechtenštejnského archivu ve Vaduzu 1173-1380. Brno.

BRETHOLZ, B., ed., 1930: Das Urbar der liechtensteinischen herrschaften Nikolsburg, Dürnholz, Lundenburg, Falkenstein, Feldsberg, Rabensburg, Mistelbacg, Hagenberg und Gnadendorf aus dem Jahre 1414. Reichenberg und Komotau.

ČERMÁK, M., 2009: Hypotetická rekonstrukce dvou fází kostela v Divicích, JM 45, 165-169.

ČERVINKA, I. L., (1942): Zapomenuté hrady, hrádky a tvrze moravské. Nepublikovaný rkp.

ČIŽMÁŘ, I.-ČIŽMÁŘ, M.-MAREČKOVÁ, J., 2007: Výsledky leteckého snímkování ÚAPP Brno na Moravě za rok 2006, PV 48, 544-549.

DRESLER, P.-TENCER, T., 2016: Neznámé opevněné sídlo v Dolních Bojanovicích - Ein unbekannter befestigter Sitz in Dolní Bojanovice, AH 41, 241-249.

DRESLER, P.-TENCER, T.-VÁGNER, M., 2015: Objev kostela na zaniklé středověké vsi Opatovice (k. ú. Hrušky) a její struktura, JM 51, 399-407.

- 2015a: Prospekce zaniklé středověké vesnice Opatovice, k. ú. Hrušky, Studia archaeologica Brunensia E 20, 113-132.

DRESLER, P.-VÁGNER, M., 2018: Zaniklé obce Břeclavska a Hodonínska: Jarohněvice a Mokronosy, Malovaný kraj. Národopisný a vlastivědný časopis Slovácka 2018, 14.

FELGENHAUER, F.-FELGENHAUER-SCHMIDT, S., 1969: Die Wüstung Gang, Gemeinde Eckartsau, p. B. Gänserndorf, Niederösterreich, Probegrabung und Versuch einer Wüstungsanalyse, Archaeologia Austriaca 10, 25-67.

GOJDA, M., 2017: Archeologie a dálkový průzkum: Historie, metody, prameny. Praha.

HABOVŠTIAK, A., 1985: Stredoveká dedina na Slovensku. Bratislava.

HLAVINKA, K.-NOHÁČ, J.-KRATOCHVÍL, A., 1926: Vlastivěda moravská. II. Místopis Moravy. Díl I místopisu, Brněnský kraj. [Čís. 45a], Hodonský okres. Brno.

HOSÁK, L., 1967: K dějinám obcí břeclavského okresu z let 1504-1541, JM 3, 32-36.

HOSÁK, L.-ŠRÁMEK, R., 1980: Místní jména na Moravě a ve Slezsku II. Praha.

HURT, R., 1934: Dějiny cisterciáckého kláštera na Velehradě I. 1205-1650. Olomouc.

- 1970: Kyjovsko. Brno.

ILČÍK, V., 1999: Dubňany v době historické. In: Dubňany, minulost a současnost moravskoslováckého města. 650 let od první písemné zmínky a 35 let od jmenování městem (Mad’eryč, P., ed.). Dubňany.

JAN, L., 2010: Středověká ves, In: Starý Poddvorov. Dějiny obce (Štěpánek, V.-Jan, L., edd.), 82-97. Starý Poddvorov.

JAN, L.-ŠTĚPÁNEK, V., edd., 2002: Mutěnice: dějiny vinařské obce. Mutěnice.

KLANICA, Z., 1963: Středověká stavba u Dubňan (okr. Hodonín), PV 7, 66.

- 1973: Mladohradištní pohřebiště v Novém Poddvorově (okr. Hodonín), PV 17, 64-65.

KLANICOVÁ, E.-MĚŘíNSKÝ, Z., 1983: Archeologické výzkumy na katastru obce Strachotín v roce 1981 (okr. Břeclav), PV 26, 47-48. 
KÜHTREIBER, K., 2015: Zu den mittelalterlichen Wüstungen im Leitharaum (The Medieval Deserted Settlements of the Leitha Region). In: Die Leitha: Facetten einer Landschaft. Vol. Spezial 3 (Doneus, M.Griebl, M., edd.), 233-247. Wien.

LEČBYCH, M., 2017: Lanžhot (okr. Břeclav) „Horní Štěpnice“, „Padělky“, PV 58, 219.

LECHNER, K., 1902: Die ältesten Belehnungs- und Lehensgerichtsbücher des Bisthums Olmütz. Brno.

MATĚJÍČKOVÁ, A., 2006: Archeologické lokality na katastru obce Vranovice, okr. Břeclav, JM 42, 241-252.

MĚŘÍNSKÝ, Z., 1976: Průzkum zaniklých středověkých osad na moravské straně Českomoravské vrchoviny v letech 1962-1970, AR XXVIII, 405-417, 479.

- 1977: Průzkum v místech zaniklé středověké osady Potvorovice, obec Nový Poddvorov (okr. Hodonín), PV 20, 70-71.

- 1982: Studium dějin osídlení na Moravě a ve Slezsku (Současný stav a další perspektivy se zvláštním zřetelem k výzkumu zaniklých středověkých vesnic) - Das Studium der Siedlungsgeschichte Mährens und Schlesiens, AH 7, 113-162.

- 1985: Archeologická topografie katastrálních území obcí v oblasti vodního díla Nové Mlýny (okres Břeclav), JM 21, 205-220.

MĚŘÍNSKÝ, Z.-UNGER, J., 1983: Archeologický výzkum pozůstatků kostela na zaniklé vsi Koválov u Žabčic, JM 19, 119-135.

- 1987: Zaniklá ves Koválov u Žabčic (archeologické nálezy). Mikulov.

MICHNA, P.-UNGER, J., 1972: Záchranný archeologický výzkum zaniklé středověké obce Teplany, okres Břeclav (informativní zpráva). In: Zaniklé středověké vesnice v ČSSR ve světle archeologických výzkumů. Díl 1, 165-168. Uherské Hradiště.

MLATEČEK, K., 2012: Zemané z Želic na cestách po Moravě, JM 48, 46-58.

NEKUDA, V., 1961: Zaniklé osady na Moravě v období feudalismu. Brno.

- 1969: Osídlení v době historické. In: Břeclavsko (Nekuda, V., ed.), 82-90. Brno.

OHAREK, V., 1892: Některé zaniklé osady na Hodonínsku, ČMM XVI, 322-324.

PILNÁČEK, J., 1930: Staromoravští rodové. Vídeň.

PLAČEK, M., 2001: Ilustrovaná encyklopedie moravských hradů, hrádků a tvrzí. Praha.

SCHARRER-LISKA, G., 2007: Überblick zu modernen und naturwissenschaftlichen Prospektionsmethoden in der Wüstungs- und Ortswüstungsforschung. In: Methodische Erfahrungen in der Ortswüstungsforschung. Die Suche nach den verschwundenen mittelalterlichen Dörfern (Bors, K., ed.), 63-78. Wien.

SMETÁNKA, Z., 1985: K ikonografii středověké vesnice, AR XXXVII, 319-333.

- 1988: Život středověké vesnice. Zaniklá Svídna. Praha.

- 2004: Legenda o Ostojovi. Praha.

UNGER, J., 1972: Povrchový sběr na zaniklé osadě Koválov u Žabčic (okr. Brno-venkov), PV 16, 106.

- 1974: K lokalizaci některých zaniklých středověkých osad v okolí Pohořelic (okres Břeclav), JM 10, $22-33$.

- 1975: Výsledky archeologického výzkumu zaniklých středověkých osad na soutoku Svratky a Jihlavy roku 1970 a 1971, Zprávy Československé společnosti archeologické XVII, 58-60.

- 1984: Zaniklá ves Topolany u Vranovic (okr. Břeclav) - Die Ortswüstung Topolany bei Vranovice, Kr. Břeclav, AH 9, 65-100.

- 1987: Podzemní chodby v jihomoravské středověké a novověké vesnici - Unterirdische Gänge im südmährischen mittelalterlichen und neuzeitlichen Dorf, AH 12, 97-110.

- 1987a: Výzkum opevněného sídla typu „motte“ na zaniklé vsi Divice u Brumovic (okr. Břeclav), PV 30, 49-51.

- 1988: „Motte“ a kostel v zaniklé vsi Divice u Brumovic, okr. Břeclav - „Motte“ und Kirche in der Ortswüstung Divice bei Brumovice (Bz. Břeclav), AH 13, 369-374.

- 1989: Feudální sídlo z 13. století na zaniklé vsi Koválov u Žabčic (archeologické nálezy). Mikulov.

- 1992: Slovo archeologie k počátkům církevní architektury na jižní Moravě. Okres Břeclav, JM 28, 7-36.

- 1994: Koválov - Šlechtické sídlo z 13. století na jižní Moravě. Brno.

- 2009: Kostel na zaniklé vsi Divice v povodí Harasky (okr. Břeclav), JM 45, 149-164.

UNGER, J.-ŠEDO, O.-KNÁPEK, R., 2017: Zaniklá ves Bohumilice u Dolních Dunajovic (k. ú. Horní Věstonice), JM 53, 225-231. 
VÁGNER, M. et al., 2018: Vágner, M.-Tencer, T.-Dresler, P.-Prištáková, M.-Šimík, J., Zaniklá stř̌edověká ves „Vsisko“ z pohledu metod nedestruktivní prospekce, Studia archaeologica Brunensia 23, 105-122. https://doi.org/10.5817/SAB2018-1-6

VAŘEKA, M., 2012: Urbář hodonínského panství z roku 1600. Hodonín.

WARNKE, D., 1993: Die Wüstung „Miltendorf“ bei Reetz im Hohen Fläming, Lkr. Potsdam-Mittelmark, Archäologie in Berlin und Brandenburg, 1990-1992, 123-128.

ZEMEK, M., 1979: Listiny jižní Moravy v lichtenštejnském archivu ve Vaduzu II 1528-1629, JM 15, $207-230$.

ZEMEK, M.-TUREK, A., 1983: Regesta listin z lichtenštejnského archivu ve Vaduzu z let 1173-1526, Sborník archivních prací Archivu ministerstva vnitra 33, 149-296.

ŽEMLIČKA, J., 1997: Čechy v době knížecí (1034-1198). Praha.

Internetová platforma obce Enzersdorf im Thale - Kleinkadolz, sekce Versunkene Orte. Dostupné z: https:// www.enzersdorf-im-thale.at/versunkene -orte/.

\section{Zusammenfassung}

\section{Neue Erkenntnisse zu umfriedeten mittelalterlichen Dörfern in Südmähren aus Sicht der Fernuntersuchung des Landes}

Belege für die Existenz von auf südmährischem Gebiet befindlichen hochmittelalterlichen umfriedeten Dörfern und Minderstädten sind im liechtensteinischen Urbar von 1414 enthalten (Bretholz 1930). Darin werden bei dreizehn bis heute existierenden Dörfern und bei vier Dorfwüstungen die Inhaber von Viertelhufen aufgeführt, die im Rahmen ihrer Untertanenpflichten auch die Pflicht hatten, das Tor, bzw. die Tore zu öffnen und zu schließen. Das führt zu dem logischen Schluss, dass diese Fundstellen in der Vergangenheit in irgendeiner Form von einer Außenbefriedung umgeben haben sein müssen. Leider lag diese Problematik im Rahmen der mährischen Mittelalterarchäologie für lange Zeit am Rande des Forscherinteresses. Eine Ausnahme bildete lediglich Z. Měř́nský, der sich Anfang der achtziger Jahre des vergangenen Jahrhunderts zu diesem Phänomen flüchtig geäußert hat (Měřínský 1982, 135). In dieser Zeit wurde auch im Intravillan der Gemeinde Strachotín eine archäologische Rettungsgrabung durchgeführt. Zu Strachotín werden im liechtensteinischen Urbar drei Viertelhufer aufgeführt, welche die Pflicht hatten, für die Nacht das Tor zu schließen. Bei der Grabung konnte außer gängigen Siedlungsobjekten auch der Teil eines 3,5-4 m breiten Grabens entdeckt werden (Klanicová-Měřínský 1983, 47; Měřínský 1985, 219), der eine Tiefe von ca. $2 \mathrm{~m}$ aufweist (Abb. 1). Aus früherer Zeit wusste man anhand von Geländeprospektionen von der Wüstung Potvorovice (Katastergebiet Nový Poddvorov; Klanica 1973; Měř́nský 1977) oder der sich auf der mährischen Seite der Böhmisch-Mährischen Höhe befindenden Wüstung Dašovice (Katastergebiet Štěmechy; Měřínský 1976). In Böhmen hat sich Z. Smetánka teilweise mit Umfriedungen bei Dorfsiedlungen beschäftigt, und zwar im Zusammenhang mit einer Analyse der ikonographischen Seite von Mandevilles Reisebeschreibung (Smetánka 1985) und in Verbindung mit der Steinumfriedung der archäologisch untersuchten mittelalterlichen Dorfwüstung Svídná (Smetánka 1988). Eine Fortentwicklung in der Untersuchung dieses Fundstellentyps kam in den neunziger Jahren des 20. Jahrhunderts, als es bei einer von M. Bálek durchgeführten Luftbildprospektion gelang, bei weiteren drei Dorfwüstungen (Koválov, Topolany und Želice) eine Außenbefriedung in Form von Gräben zu entdecken (Abb. 3, 7). Gleichzeitig gelang es bei der Dorfwüstung Hroznětice eine Umfriedung zu bestätigen (Abb. 3), zu der im liechtensteinischen Urbar zwei von vier Viertelhufern bediente Tore erwähnt werden. Die Ergebnisse der Luftbildprospektion und Oberflächensammlungen von ausgewählten Fundstellen wurden dann im Jahr 1996 von J. Unger und M. Bálek zusammengefasst (Bálek 1997, 307; Bálek-Unger 1996; 1996a).

Durch das jüngste Studium von frei zugänglichen digitalen Orthofotos und historischen Kartenarchivalien gelang es, bei folgenden Wüstungen eine Außenbefriedung zu bestätigen: Koválov (Katastergebiet Žabčice; Abb. 4:4), Hroznětice (Katastergebiet Dobré Pole; Abb. 5:9), 
Topolany (Katastergebiet Vranovice; Abb. 5:8), Želice (Katastergebiet Př́ísnotice; Abb. 5:13) und Potvorovice (Katastergebiet Nový Poddvorov; Abb. 5:11), von dessen Umfriedung man anhand von früheren Geländeprospektionen und Erinnerungen von Zeitzeugen wusste. Völlig neu gelang es bei folgenden Dorfwüstungen eine Außenbefriedung zu identifizieren: Prechov (Katastergebiet Moravský Žižkov; Abb. 4:1), Vsisko (Katastergebiet Dolní Bojanovice; Abb. 4:6), „Starý“ Mistřín” (Katastergebiet Mistřín; Abb. 4:5), Kapansko (Katastergebiet Mutěnice; Abb. 4:7), Bohumělice (Katastergebiet Horní Věstonice; Abb. 5:10), Opatovice (Katastergebiet Hrušky; Abb. 5:12). Es ist möglich, dass auch die Wüstungen Divice (Katastergebiet Brumovice; Abb. 4:5) und Jarohněvice (Katastergebiet Dubňany; Abb. 4:3) in irgendeiner Form über eine Außenbefriedung verfügt haben. Lineare Vegetationsmerkmale, die als Überreste von Gräben interpretiert werden könnten, wurden bereits von M. Bálek an den Stellen der Dorfwüstungen entdeckt (Abb. 3). Falls ja, würde die Anzahl an umfriedeten Dörfern und Minderstädten im breiteren Gebiet der niedermährischen und Thaya-Schwarzawa-Talenge somit von bisherigen einundzwanzig auf neunundzwandzig Fundstellen ansteigen (Abb. 8).

Von archäologischen Grabungen, ikonographischen Quellen und ethnologischen Analogien wissen wir, dass einzelne Anwesen, ggf. ganze Parzellen durch verschiedene Befriedungsformen voneinander abgegrenzt gewesen sein konnten. Ähnlich verhielt es sich auch bei der Konstruktion von Wohn- und Wirtschaftsgebäuden, deren Befriedungsform von der Verfügbarkeit eines konkreten Baumaterials im betreffenden Gebiet, als auch von der regionalen Bautradition abhängig war. Dabei konnte es sich um kleine Steinmauern, Holzpalisaden und Zäune oder um einfache Gebüschstreifen handeln. Diese hatten nicht nur die Aufgabe, das eigentliche Intravillan eines Dorfes zu gliedern, sondern sie konnten auch bei der Außenbefriedung des ganzen Areals eine ergänzende Rolle spielen. Falls dem so war, ist es aus funktioneller Sicht am logischsten, dass sich solche Barrieren auf der Wallspitze befunden haben. Was die Konstruktion betrifft, so erscheint es im Falle von Südmähren als am wahrscheinlichsten, dass sie die Form eines Holzzaunes hatten oder es sich um einen bloßen Streifen Flugdickicht gehandelt hat.

Wenn es um den Zweck der Befriedung selbst geht, bieten sich einige Möglichkeiten an. Die primäre Funktion, für die sich in der Vergangenheit J. Unger bereits aussprach, war eine rechtliche Funktion (Bálek-Unger 1996, 439). Bei dem Akt der Dorfgründung wurde der Umfang, ggf. die Größe der einzelnen Parzellen des betreffenden Dorfes klar abgegrenzt. Eine Außenbefriedung definierte dann den Besitz- und Rechtsumfang der betreffenden Ansiedlung und machte somit eine unterschiedliche Beurteilung von Handlungen innerhalb und außerhalb des umfriedeten Areals möglich. Ferner kann man sich vorstellen, dass ein solch umfriedetes Areal mit im voraus gegebenen Eingängen, die darüber hinaus falls nötig mit Toren geschlossen werden konnten, eine Schutz-, ggf. Verteidigungsfunktion erfüllten. Im Falle einer passiven Schutzfunktion, also ohne Beteiligung von Menschen, konnte eine Befriedung Bewegungen von Tieren verhindern. Wild konnte auf diese Weise nicht ins Innere des Areals gelangen, und umgekehrt gelangten bereits domestizierte Tiere nicht ungewollt nach draußen. Was die aktive Verteidigungsfunktion anbelangt, so konnte diese bislang weder bestätigt noch ausgeschlossen werden. Ein Graben mit einem Wall, der auf seiner Spitze darüber hinaus über irgendeine leichtere Barrierenform verfügt hätte und von der anderen Seite aktiv verteidigt worden wäre, würde eine kleinere unorganisierte Angreifergruppe wahrscheinlich abschrecken. Es bleibt die Frage, ob solche Befestigungselemente irgendeinem größeren, besser organisiertem Angriff standhalten würden. Gemäß dessen, wieviele Dörfer, umfriedete nicht ausgenommen, während den verschiedensten Kriegsereignissen verwüstet wurden, kann man annehmen, dass wahrscheinlich nicht. Im Zusammenhang mit der in der Umgebung von Enzersdorf gemachten Entdeckung von Dorfwüstungen hat sich auch der österreichische Historiker Heinz Bidner gegen den Gedanken einer Verteidigungsfunktion von Befriedungen ausgesprochen. Er nimmt an, dass die dort identifizierten durchschnittlich vier bis sechs Meter breiten und bloß zwei Meter tiefen Gräben eine solche Funktion nicht haben erfüllen können. In vielen Fällen wurde außer einem größeren Außenwall noch ein kleinerer Wall entdeckt, der sich an der Außenseite des Grabens entlang zog. Laut Bidner hätte dieser Wall bei 
einem Überfall auf das Dorf den Angreifern in Form einer potenziellen Deckung Schutz geboten. Gemeinsam mit dem Archäologen Gerhard Hasenhündl brachten sie die Hypothese vor, dass diese Gräben primär als Entwässerungskanäle bei großen Regenfällen, ggf. als Hochwasserschutz gedient haben. Nicht vergessen werden darf auch ein weiterer, ein wenig übergangener, aber in der Denkweise des damaligen Menschen sicherlich wichtiger Aspekt - der psychologische. In der „Legende von Ostoj“ (Smetánka 2004, 46-47) führt Z. Smetánka im Zusammenhang mit der Befriedung eines einfachen Anwesens aus, dass: „(...) es einen sich angeeigneten Raum, im gewissen Sinne also sicheren Raum, hier bei uns', von einem unsicheren Raum, dort hinten' unmittelbar abtrennt, also von einem sich nicht angeeigneten oder nur bedingt angeeigneten Raum, wie es für Ostoj Felder sind, und demnach einem Raum, wo besonders bei sich einstellendem Abend eine wirkliche Gefahr sowie eine, aus ungenügender Kenntnis der Welt, der Phantasie entsprungene, gedachte Gefahr droht." Diese Feststellung bezieht sich zwar nur auf Ostojs Anwesen, sie kann aber in Bezug auf die umliegende Landschaft und auf einen weit größeren Raum - beispielsweise auf ein ganzes Dorf - angewendet werden.

Auch trotz einer detaillierten Analyse aller von der Fernuntersuchung des Landes verfügbarer Quellen können die Befriedungen der beiden Dorfwüstungen Divice (Katastergebiet Brumovice) und Jarohněvice (Katastergebiet Dubňany) immer noch eine Frage der Diskussion sein, die durch eine Geländeuntersuchung überprüft werden müsste. Zu diesem Zweck hat sich eine geophysikalische Prospektion am besten bewährt. Vor kurzem ist es an einigen ausgewählten Fundstellen per Magnetometrie gelungen, sowohl die Außenbefriedung in Form von Gräben, als auch die Grundrissanordnung im Innern von Dorfwüstungen zu identifizieren. Bislang ist es gelungen, folgende Dorfwüstungen komplett zu untersuchen: Opatovice, wo unter anderem auch eine kleinere einschiffige Steinkirche identifiziert wurde (detailliert Dresler et al. 2015; 2015a), Vsisko bei Dolní Bojanovice (Vágner et al. 2018), Želice bei Přísnotice und Bohumělice bei Horní Věstonice. Bei den beiden letztgenannten Dörfern wurde durch die geophysikalische Untersuchung ein zweites in Befriedung und Grundrissdisposition ähnliches Areal entdeckt, das entweder in Supersposition zur Dorfwüstung lag (im Falle von Želice), oder sich in ihrer dichten Nähe befand (im Falle von Bohumělice). Dann wurde in der Dorfwüstung „Starý“ Mistř́n (Katastergebiet Mistř́n) teilweise eine geophysikalische Prospektion durchgeführt, wobei es gelang, die Hälfte der Dorfwüstung zu untersuchen. Ferner wurde an der südwestlichen Ecke der Dorfwüstung Prechov eine kleinere geophysikalische Kontrolluntersuchung durchgeführt, wo es gelang, eine Befriedung in Form eines Grabens zu bestätigen.

Die vorliegende Arbeit wurde von dem Projekt MUNI/A/0839/2019 „Archäologische Geländeprospektionen, Ausgrabungen, Dokumentationen und Museumspräsentationen IX“ gefördert.

Mgr. Petr Dresler, Ph.D., Ústav archeologie a muzeologie Filozofické fakulty Masarykovy univerzity, Arna Nováka 1,60200 Brno, Česká republika,dresler@phil.muni.cz

Mgr. Michal Vágner, Ústav archeologie a muzeologie Filozofické fakulty Masarykovy univerzity, Arna Nováka 1, 60200 Brno, Česká republika,vagnermichal@mail.muni.cz

Mgr. Jan Škvrňák, Historický ústav Filozofické fakulty Masarykovy univerzity, Arna Nováka 1, 60200 Brno, Česká republika,jan.skvrnak@gmail.com 
